\title{
Magnitude, spatial scale and optimization of ecosystem services from a nutrient extraction mussel farm in the eutrophic Skive Fjord, Denmark
}

\author{
Pernille Nielsen $^{1, *}$, Peter J. Cranford ${ }^{2}$, Marie Maar ${ }^{3}$, Jens Kjerulf Petersen ${ }^{1}$ \\ ${ }^{1}$ DTU Aqua, Danish Shellfish Center, Øroddevej 80, 7900 Nykøbing Mors, Denmark \\ ${ }^{2}$ Fisheries and Oceans Canada, Bedford Institute of Oceanography, 1 Challenger Dr., Dartmouth, Nova Scotia B4C 4C9, Canada \\ ${ }^{3}$ Aarhus University, Department of Bioscience, PO Box 358, Frederiksborgvej 399, 4000 Roskilde, Denmark
}

\begin{abstract}
Suspended mussel aquaculture has been proposed as a possible mechanism by which to remove excess nutrients from eutrophic marine areas. In this study, seasonal mussel growth and water clarification (through seston and phytoplankton depletion) were studied at a commercial-scale nutrient extractive mussel farm in a highly eutrophic Danish fjord. Spatial variations in mussel biomass were examined throughout the year and no significant differences were detected within the farm. Food depletion by mussels was examined at spatial scales ranging from individuals to the entire farm and surrounding area. Phytoplankton depletion on the scale of individual mussel loops, determined using the siphon mimic approach, indicated between 27 and $44 \%$ depletion of chlorophyll a (chl a). Farm-scale depletion was detected and visualized based on intensive 3D spatial surveys of the distribution of chl $a$ and total suspended particulate matter concentrations both inside and outside the farmed area. Average reductions in food supply within the farm ranged from 13 to $31 \%$, with some areas showing $>50 \%$ food depletion. A food depletion model was developed to estimate the optimal mussel density required to maximize removal of excess phytoplankton. The model employed mussel clearance rate estimates derived from the observed magnitude of food depletion within the farm. Model results indicate that the mussel population filtration rate could be increased by 80 to $120 \%$ without any negative feedback on mussel growth. This could be accomplished by approximately doubling the standing stock of mussels in the farm, hence doubling the amount of nutrients removed at mussel harvest.
\end{abstract}

\footnotetext{
*Corresponding author: peniel@aqua.dtu.dk
}

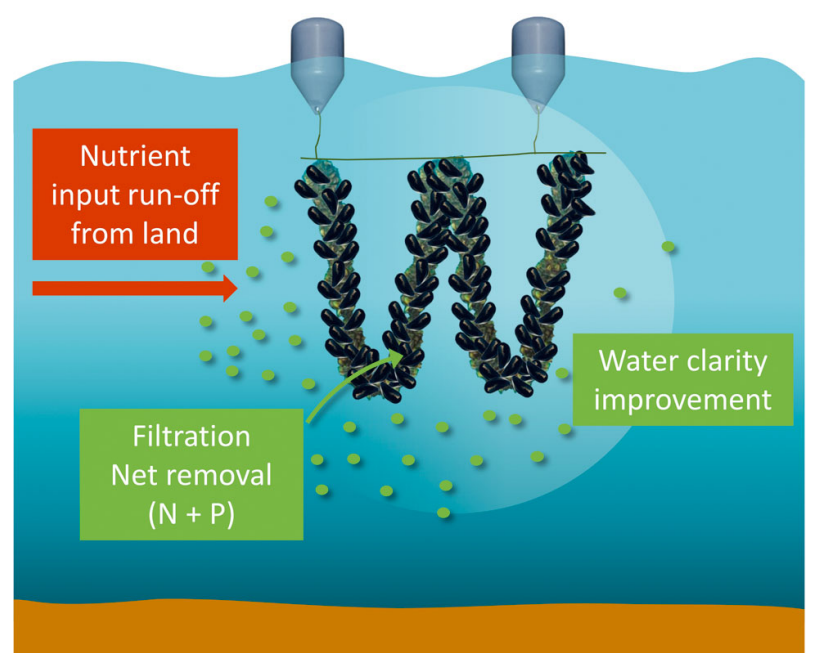

Measurements of the water clarification capacity of a nutrient extractive mussel farm in a eutrophic fjord in Denmark were used to optimize eutrophication mitigation capacity.

Graphic: Camille Saurel, DTU Aqua

KEY WORDS: Food depletion - Mussel feeding · Phytoplankton $\cdot$ Mytilus edulis $\cdot$ Nutrient extraction · Depletion model

\section{INTRODUCTION}

For decades it has been recognized that dense populations of bivalve filter-feeders possess a huge potential for clearing the water column of phytoplankton and other particulate matter (e.g. Cloern

(C) The authors 2016. Open Access under Creative Commons by Attribution Licence. Use, distribution and reproduction are unrestricted. Authors and original publication must be credited. 
1982, Officer et al. 1982, Dame 1993, 1996). The biofiltration activities of mussel populations can, under some conditions, reduce the occurrence and magnitude of algal blooms and markedly increase water clarity (e.g. Dame 1996). Commercial mussel aquaculture has been predicted and shown to reduce phytoplankton and seston biomass (i.e. depletion) at the scale of coastal ecosystems under intensive culture conditions (Grant et al. 2008). Reported levels of phytoplankton and seston reduction measured within individual mussel farms range between 10 and $80 \%$ (Heasman et al. 1998, Ogilvie et al. 2000, Strohmeier et al. 2005, 2008, Petersen et al. 2008, Cranford et al. 2014), and different zooplankton groups were reduced by 26 to $77 \%$ (Maar et al. 2008). Blue mussels Mytilus edulis can grow rapidly under eutrophic conditions because of the high phytoplankton concentrations, and transform the excess nitrogen $(\mathrm{N})$ and phosphorus (P) into mussel meat that is subsequently removed from coastal waters during the mussel harvest. Consequently, the introduction of suspended bivalve farms has been proposed as an eco-engineering approach for removing nutrients from eutrophic marine environments and improving water quality (Haamer 1996, Edebo et al. 2000, Newell 2004, Petersen 2004, Lindahl et al. 2005, Gren et al. 2009, Petersen et al. 2012, 2014，2015, Rose et al. 2012, 2015).

Studies on the concept of 'mitigation mussels' have largely been conducted under relatively small-scale conditions (e.g. Haamer 1996, Hart 2003, Lindahl et al. 2005, Gren et al. 2009, Lindahl \& Kollberg 2009) or through theoretical modelling (Hart 2003, Nunes et al. 2011, Ferreira et al. 2014, Saurel et al. 2014). The only non-pilot scale study of nutrient removal by an extractive mussel farm was that of Petersen et al. (2014), who showed that a typical Danish mussel farm (18.8 ha) in a eutrophic fjord was able to costeffectively remove 0.6 to $0.9 \mathrm{t} \mathrm{N} \mathrm{ha}^{-1} \mathrm{yr}^{-1}$ and 0.03 to $0.05 \mathrm{t} \mathrm{P} \mathrm{ha}^{-1} \mathrm{yr}^{-1}$. While that study determined the cumulative effect of the farm on total nutrient removal from the fjord, the present companion study, conducted at the same farm, addresses the spatial scale and magnitude of a related ecosystem service: increased water clarity. Performance indicators of this service include the percentage depletion of the standing stock of phytoplankton and total seston. A range of sampling methodologies and technologies were employed to quantify local to farm-scale food depletion, as well as to determine the capacity of each approach to detect food depletion.

The aim of commercial mussel aquaculture is to maximize the production of a high quality com- mercial product produced for human consumption from the farmed area, whereas the primary focus of extractive aquaculture is to maximize nutrient removal from the coastal system. While both practices generally strive to be as area-intensive and costefficient as possible, optimization criteria for extractive culture are not constrained by the quality of the product. Although stocking and husbandry practices for the optimization of extractive mussel culture have yet to be determined, it may be expected that excessive food depletion would result in reduced mussel growth (Heasman et al. 1998, Fuentes et al. 2000, Aure et al. 2007, Rosland et al. 2011) and thereby reduce the nutrient extraction potential. In the present study, spatial variations in mussel growth throughout the experimental farm were examined in conjunction with measurements of the ambient food supply to determine if growth was impacted by excessive levels of food depletion (i.e. negative feedback). To further explore possible optimization options for nutrient extraction, field measurements were integrated into a farm-scale food depletion model. The model was used to estimate the mussel density required to maximize the removal of excess phytoplankton, and thereby improve water quality.

\section{MATERIALS AND METHODS}

\section{Study site}

The mussel farm and sampling stations were located in the Skive Fjord, Denmark: a small estuary in the western part of Limfjorden (Fig. 1). The fjord has a surface area of $49 \mathrm{~km}^{2}$, a low tidal range $(<0.3 \mathrm{~m})$, and a mean depth of $4.7 \mathrm{~m}$. This estuary is partially mixed, with stratification on the scale of days to weeks depending on fresh water inflow, solar radiation and wind (Møhlenberg 1999). Skive Fjord can be classified as eutrophic based on the frequent oxygen depletion events, high dissolved nutrient and chlorophyll a $(\mathrm{chl} a)$ concentrations, high sedimentation rates of organic-rich particulate matter, sparse benthic communities and rapid nutrient regeneration in the water column and sediments (Maar et al. 2010, Carstensen et al. 2013)

A commercial-scale mussel farm was rented for experimental purposes in a region where the water depth ranged from 5 to $7 \mathrm{~m}$. The farm covered an area of approximately $250 \times 750 \mathrm{~m}(18.8 \mathrm{ha})$ and was divided into 3 sections (north, middle and south), each containing 30 long-lines ( $200 \mathrm{~m}$ each) that ran parallel to the shore (Fig. 1C). Buoys and anchors 

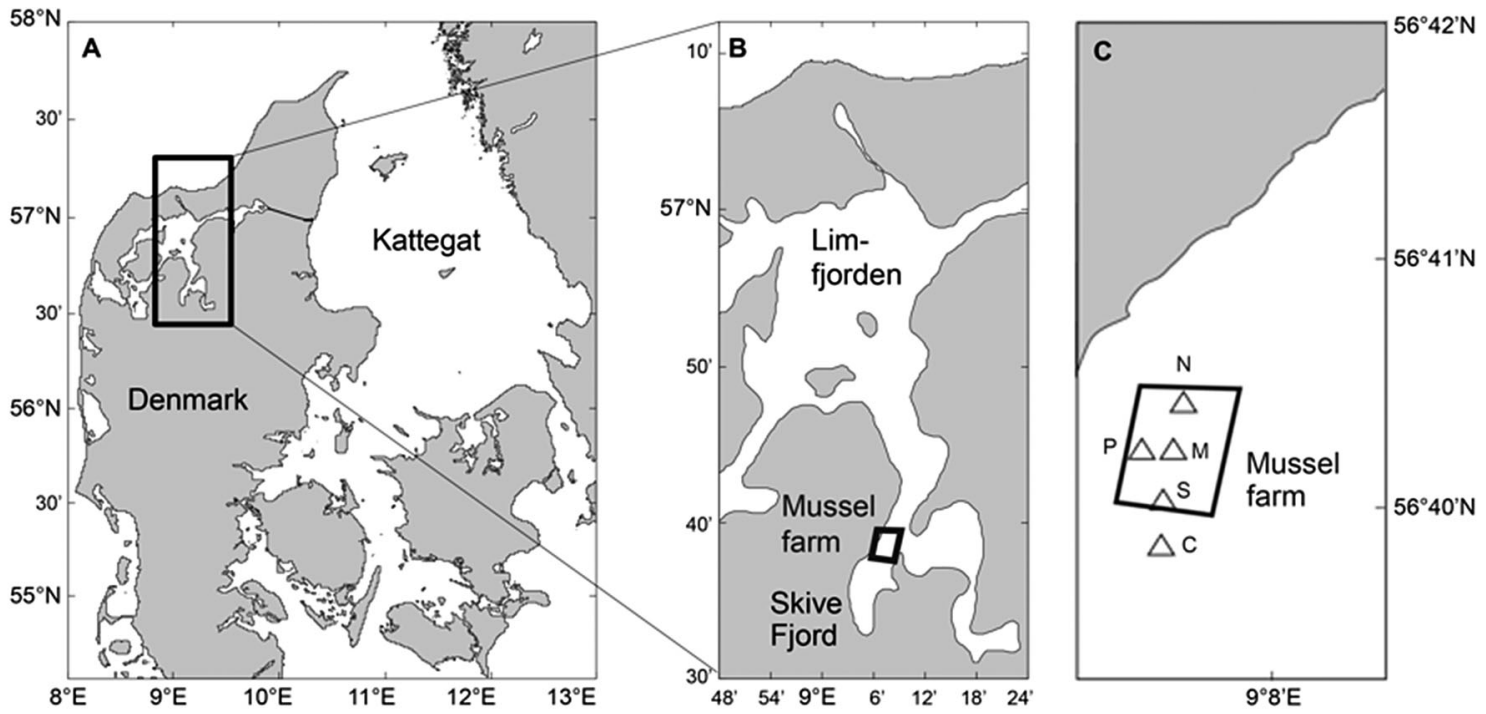

Fig. 1. $(\mathrm{A}, \mathrm{B})$ Location of the Limfjorden, Denmark and $(\mathrm{C})$ the position of the mussel farm and sampling stations in the Skive

Fjord. Stations: $\mathrm{N}=$ north section; $\mathrm{M}=$ middle section; $\mathrm{S}=$ south section; $\mathrm{C}=$ outside the farm; $\mathrm{P}=$ siphon mimic samples

maintained the long-lines at a depth of 0.5 to $1 \mathrm{~m}$ below the water surface. Vertical mussel loops were attached to the long-lines at $0.5 \mathrm{~m}$ spacing and hung to a maximum depth of $2 \mathrm{~m}$ below the long-line. A total of $90 \mathrm{~km}$ of mussel loops were deployed within the farm. The farm was self-recruiting; blue mussel larvae were first observed in Skive Fjord in May 2010 (P. Nielsen pers. obs.) and the larvae had settled on the mussel loops by the end of May to the beginning of June 2010. The study period lasted from June 2010 until June 2011, and included seasonal mussel rope and water column sampling as well as 2 intensive $12 \mathrm{~d}$ field campaigns (23 August to 3 September 2010, and 2 to 13 May 2011). Skive Fjord was covered by ice (20 to $32 \mathrm{~cm}$ thick in January 2011) from the beginning of December 2010 until the end of February 2011.

\section{Mussel growth}

Mussel rope samples (including mussels and biofouling) were collected by randomly removing approximately $1 \mathrm{~m}$ sections of mussel loops from different sections of the farm. These samples were used to examine spatial and temporal variations in mussel biomass and growth within the farm. Mussel ropes were sampled on 7 random occasions from July 2010 until June 2011 from the same lines in each of the 3 farm sections. On each sampling occasion, 10 rope samples were collected from each section (total: 30 samples). The first $1 \mathrm{~m}$ of the loop was discarded; the next $1 \mathrm{~m}$ section of mussel loop was removed and collected in a plastic bag for transport to the laboratory. In addition, 9 rope samples (3 from each section) were collected from the middle and edge lines between August and November to further examine spatial variations in mussel growth within the farm. In December 2010, the ice severed the edge line, so further sampling and comparisons of edge versus middle lines were not possible.

The following measurements were taken for each mussel rope sample: exact length of rope, total wet weight (WW, in $\mathrm{kg}$ ) including mussels and biofouling, no. of mussels kg ${ }^{-1} \mathrm{WW}$, WW (kg) of mussels and WW $(\mathrm{kg})$ of byssus. Individual mussels were randomly selected from each rope sample for measurements of shell length $(n=100)$ with a digital caliper $( \pm 1 \mathrm{~mm})$ and individual tissue and shell dry weight $(\mathrm{DW}, \mathrm{n}=10$ ). Mussel tissue and shell were separated and dried at $80^{\circ} \mathrm{C}$ for $\geq 5 \mathrm{~d}$, cooled to room temperature in a desiccator and weighed to the nearest $\mathrm{mg}$.

Mussel growth within each of the 3 farm sections was determined from seasonal changes in average tissue mass. The weight-specific growth rate of Mytilus edulis $\left(\mu, \mathrm{d}^{-1}\right)$ was calculated as:

$$
\mu=\ln \left(\frac{\mathrm{DW}_{t}}{\mathrm{DW}_{0}}\right) \times t^{-1}
$$

where $\mathrm{DW}_{t}$ and $\mathrm{DW}_{0}$ are the mean dry weights of mussel tissues on Day 0 and Day $t$, respectively. The actual weight-specific growth rates were compared with measured maximum growth rates of mussels deployed in net-bags from 6 other studies conducted 
in Danish waters (Riisgård \& Poulsen 1981, Riisgård et al. 2012, 2014, Landes et al. 2015). The measured maximum growth rate $(\mathrm{n}=6$, mussel weight $0.049 \pm$ $0.035 \mathrm{mg}$; mean $\pm \mathrm{SD}$ ) was on average $7.6 \% \mathrm{~d}^{-1}$, and was compared with present values using an allometric biomass scaling of 0.34 (Riisgård et al. 2012), and corrected for temperature effects by the Arrhenius equation (van der Veer et al. 2006).

Mussel biomass ( $\mathrm{kg} \mathrm{WW} \mathrm{m}^{-1} ; \mathrm{n}=10$ ) and tissue DW ( $n=100$ ) were compared between sections for the different sampling dates using a fixed factor (Model I) 2-way ANOVA (GraphPad Prism v.5.0f). Mussel biomass ( $\mathrm{n}=3$ ) and DW ( $\mathrm{n}=30)$ were compared between the middle and edge lines for each section of the farm on the different sampling dates using unpaired Student's $t$-tests $(\alpha=0.05)$. Any change in DW during ice-cover was determined by comparing DW data from October (before ice) with data from March (right after ice) by using a Mann-Whitney $U$ test $(\alpha=0.05)$. Homogeneity of variances and normality were assured for the above datasets according to Bartlett's test and D'Agostino-Pearson omnibus normality test.

\section{Water currents}

Water currents replenish the food supply in the mussel farm and are therefore important for modelling changes in food concentrations across the farm. Current speed and direction within and around the farm was measured using a boat-mounted $1200 \mathrm{kHz}$ acoustic Doppler current profiler (Workhorse Monitor, Teledyne RD Instruments). These data were collected simultaneously with the spatial surveys of suspended particulate matter and chl a concentrations (see 'High-resolution synoptic survey approach' below), and were averaged for water depths between 1 and $4 \mathrm{~m}$.

\section{Small-scale phytoplankton depletion}

Food depletion by mussels quantified at the scale of individual mussel ropes $(0.1$ to $50 \mathrm{~cm}$ from the mussels) was examined during 2 field campaigns (3 times in August 2010 and 4 times in May 2011) using the siphon mimic technique (Petersen et al. 2008, 2013). This method consists of small tubes by which water (i.e. chl a) is sampled at 5 different distances $(0.1,5,10,20$ and $50 \mathrm{~cm})$ from the edge of the mussel shells. The day before the first water sample was taken, 2 siphons (each siphon included the 5 sam- pling distances) were positioned by a SCUBA diver on a mussel loop in the middle farm section near the farm edge (Stn P in Fig. 1C). The siphons were positioned at $2 \mathrm{~m}$ depth with one siphon aligned perpendicular to the long-line and the other, parallel. Data collected using both siphon orientations were averaged to control for any current direction bias in the results. During each sampling period, water from both siphons and all 5 distances was simultaneously pumped to the surface for 4 to $7 \mathrm{~min}$ at $4 \mathrm{l} \mathrm{h}^{-1}$ using a peristaltic pump. Water samples were collected in triplicate in 0.31 glass bottles for analysis of chl a and phaeopigments in different size fractions as described below. The average percentage food depletion at a given distance from the mussels was calculated as:

$$
\text { Depletion }(\%)=\frac{\left(C_{0}-C_{X}\right)}{C_{0}} \times 100
$$

where $C_{X}$ and $C_{0}$ are average chl a concentrations at the given distance from the mussels and at $50 \mathrm{~cm}$ from the mussels, respectively. Food depletion was determined when linear regression analysis of food concentration at the different distances indicated a slope that was significantly different from zero.

\section{Farm-scale phytoplankton and seston depletion}

\section{Discrete sampling approach}

On 22 occasions between June 2010 and June 2011, a standard monitoring program consisting of CTD-casts and water sampling was conducted to characterize environmental conditions at 4 permanent sampling stations located inside and outside the farm area. Sampling stations were positioned at 2 edges of the farm (Stns $\mathrm{N}$ and $\mathrm{S}$ ), in the center of the farm (Stn M) and $300 \mathrm{~m}$ south of the farm (Stn C) (Fig. 1C). The CTD-profiles were conducted using a calibrated conductivity-temperature-depth sensor and an integrated chl a fluorescence sensor (ECO-probe, Meerestechnik Elektronik). Spatial differences in fluorescence on different sampling occasions were compared between the stations within the farm $(\mathrm{N}, \mathrm{S}$, $\mathrm{M})$ as well as with the control station outside the farm (C), to determine if food depletion could be detected using this sampling approach. Salinity profiles from each station were also compared to ensure that water properties at all stations were uniform. All station comparisons were conducted using 1-way ANOVA, and significant results were followed by a Tukey's post hoc test or Dunn's multiple comparison tests. 
Homogeneity of variances and normality were assured for all datasets according to Bartlett's test and D'Agostino-Pearson omnibus normality test.

Water sampling was conducted on the same dates as the CTD-casts at Stns M and C. Samples were collected with a 1.7 l Ruttner water sampler (KC Denmark) from a depth of $1 \mathrm{~m}$. Water samples were kept in the dark during transport to the laboratory, where they were immediately and gently pre-filtered through a $200 \mu \mathrm{m}$ mesh to avoid possible inclusion of mussel fecal pellets. The pre-filtered water samples were then analysed for size-fractionated chl a by filtering either 50 or $100 \mathrm{ml}$ duplicate sub-samples through Whatman GF/F and GF/D filters (0.7 and $2.7 \mu \mathrm{m}$ nominal pore size). Chl $a$ and phaeopigments were extracted from the filters in $10 \mathrm{ml}$ of $96 \%$ ethanol, and analysed by the fluorometric technique of Holm-Hansen et al. (1965) using a Turner Designs 10-AU fluorometer calibrated against a chl a standard (PPS-CAPSA, DHI).

\section{High-resolution synoptic survey approach}

Farm-scale depletion was also investigated based on intensive spatial surveys of the horizontal and vertical distribution of chl $a$ and total suspended particulate matter (TPM) concentrations inside and outside the farmed area (Cranford et al. 2008). This towed sensor approach provides depth-averaged maps (contour plots) of particle concentrations in and around the farm, providing a synoptic description of the effect of the mussel farm's impact on chl $a$ and TPM concentrations. Spatial data on TPM and chl a concentrations were collected using in situ electronic sensors mounted on a computer controlled, undulating tow vehicle (Acrobat LTV-50, Sea Sciences). The sensor payload consisted of a CTD (AML Oceanographic MicroCTD), a chl a fluorometer (Seapoint Sensors) and a transmissometer with a $25 \mathrm{~cm}$ optical path length (c-Rover CRV5, WET Labs). For all surveys, the Acrobat was programmed to automatically undulate between 0.5 and $5 \mathrm{~m}$ depth. The instruments were powered from the surface by $12 \mathrm{~V}$ leadacid batteries, and all measurements were made at a sampling frequency of $1 \mathrm{~Hz}$. Tow speed was maintained at approximately $2 \mathrm{~m} \mathrm{~s}^{-1}$, and the sensor data stream was combined in real time with simultaneous GPS and water depth readings (Model GPSMAP 421, Garmin) using Windmill 7 data acquisition and visualization software (Windmill Software). Acrobat surveys were conducted on 7 occasions during the 2 field campaigns ( 3 between 28 August and 1 Septem- ber 2010, and 4 between 4 and 10 May 2011) and included data collection inside the farm (tows between multiple mussel long-lines) and in all directions outside the farm. A typical survey was completed within a $2 \mathrm{~h}$ period.

An in situ calibration of the Acrobat fluorometer and transmissometer was conducted using seawater samples collected from areas outside the farm in order to avoid mussel faecal pellets. Water was collected at the same depth as the Acrobat with a 21 Kemmerer water sampler. Water samples stored in pre-rinsed 11 Nalgene bottles were kept in the dark during transport and filtered through pre-washed Advantec GC-50 glass fiber filters $(0.5 \mu \mathrm{m}$ porosity; $\mathrm{n}=1$ for chl $a$ and $\mathrm{n}=3$ for TPM analysis). The chl $a$ content of particles was determined as described above. The relationship between measured chl a $(\mu \mathrm{g}$ $\mathrm{l}^{-1}$ ) and the Seapoint fluorescence voltage (FLV, in $\mathrm{mV}$ ) was determined using regression analysis ( $\mathrm{chl} a$ $\left.=5.007 \times \mathrm{FLV}+0.970 ; \mathrm{n}=46, \mathrm{r}^{2}=0.93\right)$. The material collected on TPM filters was rinsed with isotonic ammonium formate to remove salt, dried at $60^{\circ} \mathrm{C}$ and weighed to the nearest $0.01 \mathrm{mg}$ for determination of TPM concentration $\left(\mathrm{mg} \mathrm{l}^{-1}\right)$. The relationship between TPM concentrations and c-Rover instrument counts was also determined by regression $(\mathrm{TPM}=-11.863 \times$ $\ln ($ counts $)+17.883 ; \mathrm{n}=101, \mathrm{r}^{2}=0.84$ )

Vertical profile plots and contour maps of water density (Sigma- $t_{;} \sigma_{\mathrm{T}}$ ), chl $a$, and TPM concentrations were used to summarize and observe spatial patterns in each of these parameters during each Acrobat survey. Depth intervals exhibiting low vertical variation in the measured parameter were selected for contour mapping using Surfer 9 (Golden Software) and the Ordinary Kriging interpolation method. The average percentage food depletion within the total farm volume $\left(D_{X}\right)$ was calculated using Eq. (2), where $C_{X}$ and $C_{0}$ are average chl $a$ or TPM concentrations within the farm and reference areas, respectively. The reference area included all data collected outside the farm boundaries with the exception of any plume of depleted mussel food moving away from the farm, which was identified from the contour maps of TPM and chl a concentration. Food depletion was also calculated at various distances in the direction of the current flow across the mussel farm by extracting subsets of the Acrobat survey data for preselected areas. For these calculations, all data collected immediately adjacent to the inflow side of the farm served as the reference (i.e. $C_{0}$ ) while data from parallel sections located in the center and outflow side of the farm represented food concentrations impacted by mussel feeding (i.e. $C_{\mathrm{x}}$ ). 
Eq. (2) assumes that spatial variations within the survey domain are solely caused by the feeding activity of the farmed mussels and not by natural variability. Consequently, care was taken to ensure that food depletion was only calculated for sampling periods that exhibited uniform water properties (a single water mass) within the surveyed area. This was particularly important for the Skive Fjord, which exhibited a high degree of patchiness in water density during this study due to freshwater run-off. Given the possible presence of more than one water mass within the farm during each survey, contour plots of $\sigma_{\mathrm{T}}$ were first examined prior to any calculation of food depletion. While it may be expected that the level of farm-scale TPM and chl a depletion would be similar on consecutive sampling days, several surveys had to be conducted during each sampling campaign to obtain a survey that conformed with the methodological assumption of water mass uniformity. Of the 7 surveys conducted, only the data collected on 1 September 2010 and 10 May 2011 were consistent with this assumption.

\section{Depletion model}

The food supply to the farmed mussels is determined by water transport into the farm, the upstream food concentration and the farm design. Food concentrations are progressively reduced as the water flows through the farm due to mussel filtration. A simple 1D horizontal depletion model was applied to describe changes in food concentrations across the farm. The depletion model assumes a constant unidirectional flow, a fully mixed surface layer, a uniform distribution of mussels, and that dispersion and vertical transport are disregarded (Bacher et al. 2003). The depletion rate of food concentration $\left(C_{i} \mathrm{mg} \mathrm{m}^{-3}\right)$ is described as:

$$
\partial t=-\bar{u} \frac{\mathrm{d} C}{\mathrm{~d} x}+C(x, t) \times N \times \mathrm{CR}
$$

where $N$ is the density of mussels (ind $\mathrm{m}^{-3}$ ), CR is the realized clearance rate of mussels $\left(\mathrm{m}^{3}\right.$ ind..$\left.^{-1} \mathrm{~s}^{-1}\right), x$ is the downstream distance $(\mathrm{m})$ and $\bar{u}$ is the average current velocity $\left(\mathrm{m} \mathrm{s}^{-1}\right)$ in the middle of the farm. Current velocities measured inside the farm were used to account for the effect of mussel structure drag on currents (Cranford et al. 2014). Current speeds within the farm averaged $0.027 \mathrm{~m} \mathrm{~s}^{-1}$ and are in accordance with previously measured current speeds in and around mussel farms in Skive Fjord (Stevens \& Petersen 2011). Published CR values for individual
$M$. edulis of standard size vary over a wide range, owing largely to responses to ambient food concentration and composition; in situ CR measurements can differ greatly from the theoretical maximum (e.g. Maar et al. 2008, Cranford et al. 2011). Re-filtration of water by dense populations, particularly during periods of low flows and reduced turbulent mixing, also affects predictions of food depletion rates (Saurel et al. 2013, Cranford et al. 2014). Instead of employing CR values from previous studies for modelling purposes, the average realized CR of the farmed mussels was calculated by solving Eq. (3) analytically assuming steady-state conditions $(\partial t=0)$. We assumed constant food depletion $\left(C_{X} / C_{0}\right)$, current velocity and density of mussels within a uniform water mass during each sampling period in the estimation of an average realized CR:

$$
\mathrm{CR}=\frac{-\ln \left(\frac{C_{x}}{C_{0}}\right)}{x \times N} \times \bar{u}
$$

where $C_{X}$ and $C_{0}$ are the downstream and upstream food concentrations, respectively. The ratio $C_{X} / C_{0}$ was the average depletion across the length $(x)$ of the mussel farm measured on 1 September 2010 and 10 May 2011 using the Acrobat survey data. Eq. (4) was applied for a single farm section $(250 \times 200 \mathrm{~m})$ with $x$ set as half the distance across the section in the prevailing current direction and $C_{X} / C_{0}$ measured in the center of the section using subsets $\left(C_{0}=\right.$ inflow side and $C_{X}=$ farm center) of the Acrobat survey data. The complete farm was not modelled owing to potential complications imposed by the $50 \mathrm{~m}$ of open water that separated each farm section in which vertical and horizontal mixing could occur, and possible enhanced mixing at the edges of the farm (see 'Discussion'). In September, the current direction was approximately $270^{\circ}$ and the distance to the center of the farm section was $125 \mathrm{~m}$, whereas in May the current direction was $180^{\circ}$ and $x=100 \mathrm{~m}$. Realized CR was estimated from Eq. (4) for the average ( \pm SD) abundance of mussels measured on the corresponding sampling dates.

The growth rate, $\mu\left(\mathrm{d}^{-1}\right)$, of mussels was estimated from CR as:

$$
\mu=\frac{\left(\mathrm{CR} \times C \times \mathrm{AE}-R_{\mathrm{m}}\right)}{B \times R_{\mathrm{a}}}
$$

where $B$ is the individual biomass (g DW, see Table 2), and assimilation efficiency, $\mathrm{AE}=0.75$ (van der Veer et al. 2006), active respiration, $R_{\mathrm{a}}=1.12$ (Clausen \& Riisgård 1996) and maintenance respiration, $R_{\mathrm{m}}=$ $0.475 \times \mathrm{DW}^{0.66}$ (Hamburger et al. 1983). Model sce- 
narios with increasing mussel densities were conducted using the following equation to test the effect on downstream chl a concentrations and percentage depletion (Eq. 2). Downstream concentrations at distance $x(m)$ were estimated from:

$$
C_{X}=C_{0} \exp \left(\frac{-\mathrm{CR} \times N \times x}{\bar{u}}\right)
$$

Scenarios with increasing mussel densities were run for the September 2010 and May 2011 sampling periods using the realized CR values (see Table 4). This assumes that re-filtration at the scale of individual mussel ropes was independent of the number of ropes present on each date. The scenarios were tested for the range of measured upstream chl a concentrations from May to October. A lower target threshold for phytoplankton concentration was set

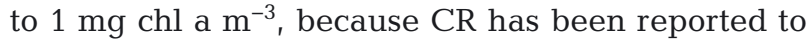
reduce at 0.5 to $1.0 \mathrm{mg} \mathrm{m}^{-3}$ (Dolmer 2000b, Riisgård et al. 2006, Saurel et al. 2007, Pascoe et al. 2009). The total population filtration rate $\left(F, g \mathrm{DW} \mathrm{m}{ }^{-3} \mathrm{~d}^{-1}\right)$ for one farm section was calculated as:

$$
F=\mathrm{CR} \times C \times N
$$

where $C$ is the average chl a concentrations converted to DW using a DW:C ratio of 2.5 (Smaal et al. 1997) and $C$ :chl a ratio of 30 (Olesen \& Lundsgaard 1995).

\section{RESULTS}

\section{Mussel biomass and growth}

The density (no. $\mathrm{m}^{-1}$ ) and biomass $\left(\mathrm{kg} \mathrm{WW} \mathrm{m}^{-1}\right.$, including meat and shell) of mussels, averaged over the 3 sections (north, middle and south) of the mussel farm are presented in Table 1, along with the measured total amount of nitrogen and phosphorus re- moved in December 2010, March and May 2011 (data from Petersen et al. 2014). Mussel density decreased exponentially over the experiment through selfthinning, The highest mussel biomass (1100 t WW) was reached in May 2011, which also resulted in the highest amount of nutrients removed (Table 1). Mussel biomass increased during the growth season, except during winter when the farm was covered with ice (Fig. 2). No significant differences in mean mussel biomass ( $\mathrm{kg} \mathrm{WW} \mathrm{m}^{-1}$ rope) among the 3 sections were detected on each sampling date $(p=0.07$; Table 2$)$, although the mean effect between dates was highly significant (Table 2). In addition, no differences were observed ( $p>0.09)$ when comparing the mean DW of individual mussel tissue from the 3 sections on each sampling date (data not shown). Fig. 3 shows the biomass ( $\mathrm{kg} \mathrm{WW} \mathrm{m}^{-1}$ rope) of whole mussels (meat and shell) collected at the edge line and middle line on 4 different sampling dates in 2010. No significant differences for any of the 4 sampling dates were detected when comparing mussel biomass (Student's $t$-test, $p>0.26$ ) or mean DW of mussel tissue (data not shown; Student's $t$-test, $\mathrm{p}>0.08$ ) collected from the edge line versus middle line at a given sampling date.

Since no significant spatial differences in mussel biomass or dry tissue mass were observed on any given sampling date, data from all sections were pooled and the average farm values for the different samplings dates (mussel tissue DW data from July was not estimated) were used to calculate growth rates. The highest specific growth rate $\left(7.1 \% \mathrm{~d}^{-1}\right)$ was observed in August-September (Fig. 4), whereas from October until March, mussel tissue DW decreased (Mann-Whitney $U$-test, $\mathrm{p}=0.003$ ) resulting in a negative specific growth rate for that time period (Fig. 4). The estimated growth rates were 48 to $57 \%$ of maximum from September to March, but at maximum from March to May (Fig. 4).

Table 1. Mean $( \pm \mathrm{SD})$ values, taken on 7 different sampling dates, of blue mussel Mytilus edulis shell length, tissue dry weight (DW), biomass (wet weight, WW $\mathrm{m}^{-1}$ of rope), estimated farm mussel biomass, density of mussels $\mathrm{m}^{-1}$ of rope and estimated total amount of nitrogen (N) and phosphorus (P) in the mussels (meat, shells and byssus) at the extractive mussel farm shown in Fig. 1. Data on N and P removed are from Petersen et al. (2014). na: not available

\begin{tabular}{|lcccccc|}
\hline Date & $\begin{array}{c}\text { Shell length } \\
(\mathrm{mm})\end{array}$ & $\begin{array}{c}\text { DW } \\
(\mathrm{g})\end{array}$ & $\begin{array}{c}\text { Biomass } \\
\left(\mathrm{kg} \mathrm{WW} \mathrm{m}^{-1}\right)\end{array}$ & $\begin{array}{c}\text { Farm biomass } \\
(\mathrm{t} \text { WW })\end{array}$ & $\begin{array}{c}\text { Mussel density } \\
\left(\text { ind. } \mathrm{m}^{-1}\right)\end{array}$ & $\begin{array}{c}\mathrm{N} \text { and P } \\
\text { removed }(\mathrm{t})\end{array}$ \\
\hline 14 Jul 2010 & $6.2 \pm 1.5$ & na & $1.3 \pm 0.6$ & $119 \pm 55$ & $52070 \pm 23318$ & $\mathrm{na}$ \\
3 Aug 2010 & $11.6 \pm 4.3$ & $0.015 \pm 0.007$ & $1.6 \pm 0.6$ & $146 \pm 54$ & $6401 \pm 1935$ & na \\
1 Sep 2010 & $21.0 \pm 5.1$ & $0.135 \pm 0.054$ & $5.7 \pm 1.8$ & $513 \pm 160$ & $4621 \pm 1527$ & na \\
27 Sep 2010 & $27.1 \pm 6.6$ & $0.236 \pm 0.102$ & $8.1 \pm 1.8$ & $732 \pm 163$ & $4099 \pm 1223$ & na \\
28 Oct 2010 & $30.7 \pm 9.4$ & $0.359 \pm 0.147$ & $9.5 \pm 3.5$ & $855 \pm 315$ & $2937 \pm 790$ & N: 11, P: 0.5 \\
16 Mar 2011 & $30.4 \pm 10.0$ & $0.261 \pm 0.162$ & $7.0 \pm 2.7$ & $629 \pm 241$ & $2551 \pm 1185$ & N: 10.5, P: 0.5 \\
10 May 2011 & $37.2 \pm 12.0$ & $0.547 \pm 0.241$ & $12.2 \pm 2.1$ & $1098 \pm 188$ & $2316 \pm 699$ & N: $16, P: 0.7$ \\
\hline
\end{tabular}




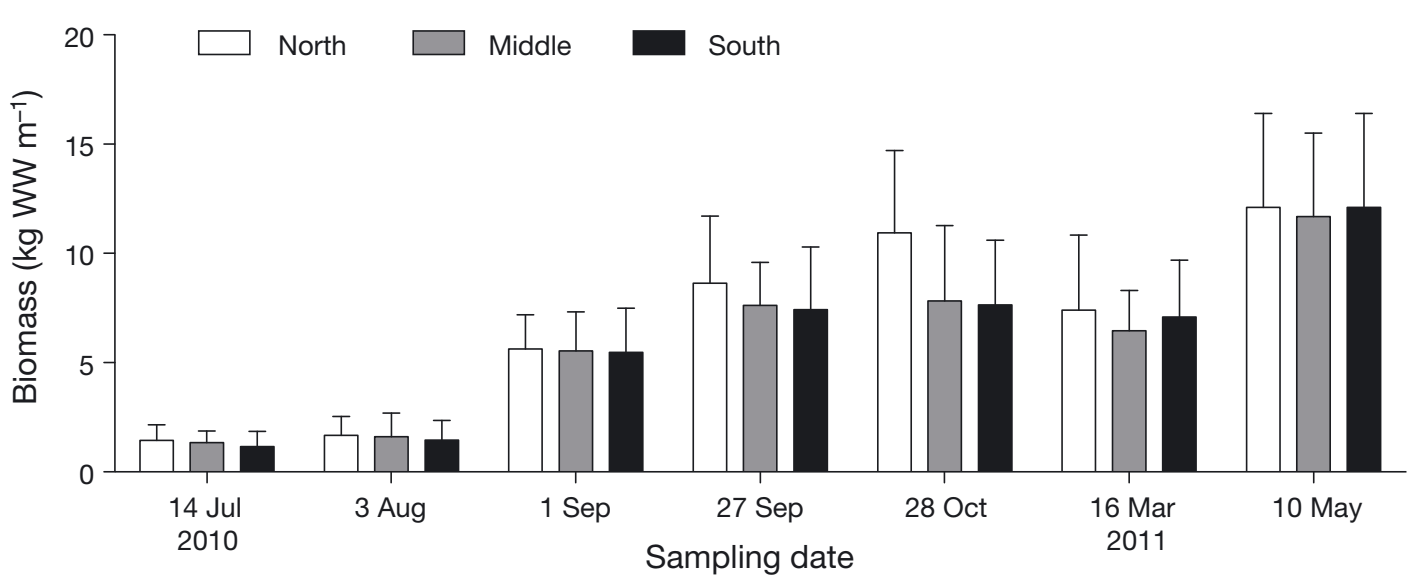

Fig. 2. Mean (+SD) mussel wet weight (WW) biomass $\mathrm{m}^{-1}$ of rope $(\mathrm{n}=30$ biomass samples for each section at each sampling date, except for south on 16 March and 10 May 2011, where $n=5$ ) from the 3 different sections in the mussel farm (north, middle and south) on 7 different sampling dates during the 2010-2011 growth season

Table 2. Results from 2-way ANOVA testing overall differences in mussel biomass $\left(\mathrm{kg} \mathrm{WW} \mathrm{m}^{-1}\right)$ collected at the different sections (north, middle and south) of the mussel farm and on different sampling dates

\begin{tabular}{|lcccc|}
\hline & df & MS & $F$ & $p$ \\
\hline Section $\times$ sampling day & 10 & 4.435 & 0.8406 & 0.59 \\
Sections & 2 & 14.26 & 2.703 & 0.07 \\
Sampling day & 5 & 273.3 & 51.8 & $<0.0001$ \\
Residual & 147 & 5.275 & & \\
\hline
\end{tabular}

\section{Water clarification by extractive mussels}

\section{Phytoplankton standing stock in Skive Fjord}

Chl a concentrations at Stns $\mathrm{M}$ and $\mathrm{C}$ varied from 3.8 to $26.6 \mu \mathrm{g} \mathrm{chl} \mathrm{a} \mathrm{l}^{-1}$ during the year, with the highest concentrations measured in June, July and

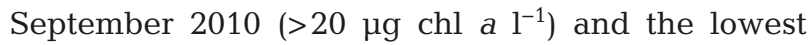

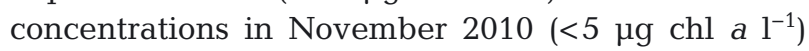
(Fig. 5). With the exception of April and November, chl a concentrations in Skive Fjord exceeded Danish Nature Agency and EU threshold values for 'bad' or 'poor' status (https://goo.gl/RjqCcz). The mean $( \pm \mathrm{SE})$ chl a concentration was not significantly different (Wilcoxon paired $t$-test, $\mathrm{p}=0.80)$ between $\mathrm{Stn} M(12.7 \pm$ $\left.1.7 \mu \mathrm{g} \mathrm{chl} \mathrm{a}^{-1}\right)$ and Stn C (13.3 $\left.\pm 2.2 \mu \mathrm{g} \mathrm{chl} \mathrm{a} \mathrm{l}^{-1}\right)$.

\section{Small-scale phytoplankton depletion}

The siphon mimic measurements typically showed a gradient in chl a concentrations ( $>3 \mu \mathrm{m}$ size fraction) from the mussels out to a distance of 10 to $20 \mathrm{~cm}$ on each sampling date (Fig. 6). The average ( $\pm \mathrm{SE})$ depletion percentage in water immediately adjacent to mussels in August 2010 and May 2011 was $44 \pm$ $11 \%$ and $27 \pm 4 \%$, respectively (Fig. 6A), which corresponded to mean $( \pm \mathrm{SD}) \mathrm{chl}$ a concentrations at the farm of $7.4 \pm 2.2$ and $11.9 \pm 5.4 \mu \mathrm{g} \mathrm{chl} \mathrm{a} \mathrm{l}^{-1}$. A clear depletion gradient in the $>3 \mu \mathrm{m}$ particle size fraction was observed for 6 out of 7 sampling days (linear regression analysis; $\mathrm{p}=0.07$ and $\mathrm{p}=0.03$ for August 2010 and May 2011, respectively; data not shown). The picoplankton fraction $(0.2$ to $3 \mu \mathrm{m})$, which is ineffectively captured by mussels and served as a control for any other possible effects on the phytoplankton distribution, did not exhibit a depletion gradient for any sampling date (Fig. 6B).

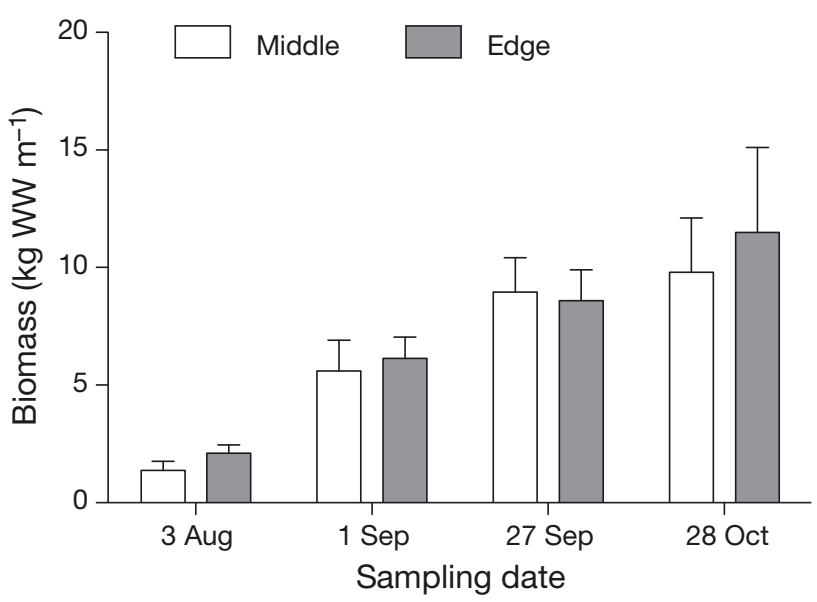

Fig. 3. Mean (+SD) mussel wet weight $(\mathrm{WW})$ biomass $\mathrm{m}^{-1}$ of rope $(\mathrm{n}=9$ biomass samples for each section at each sampling date) at the edge and middle lines in the mussel farm sampled on 4 different dates in 2010 


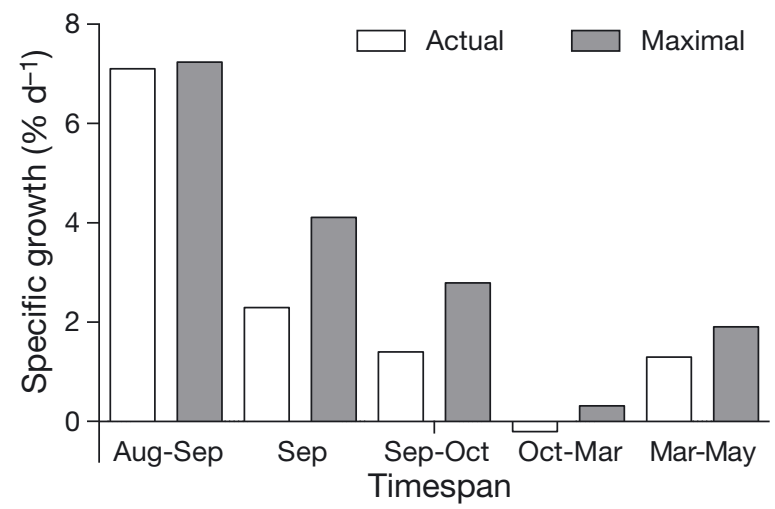

Fig. 4. Average specific growth rates of individual mussels (\% $\mathrm{d}^{-1}$ ) measured within the experimental farm (white bars) and the corresponding calculated potential maximal growth (grey bars) for selected periods (see 'Materials and methods')

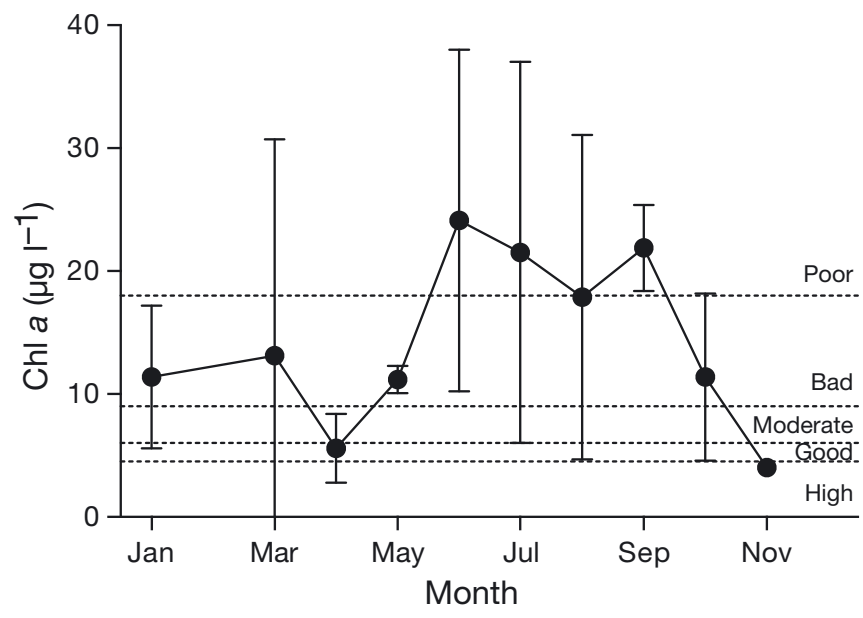

Fig. 5. Mean $( \pm \mathrm{SD})$ chl a concentrations in Skive Fjord during 2010-2011. Data were collected at Stns M and C (see Fig. 1). Also shown are threshold values for the Water Frame Directive separating the ecological states 'high', 'good', 'moderate', 'bad' and 'poor' (horizontal lines)

Farm-scale seston and phytoplankton depletion

It was generally not possible to detect the depletion of phytoplankton by comparing the results of chl $a$ fluorescence obtained with discrete CTD-casts within and near the farm during the study period. Comparison of fluorescence was only done on sampling days when the salinity profiles measured at the 4 sampling stations ( $N, M, S$ and $C$ ) exhibited uniform water properties (e.g. same salinity profile at each station). The mean salinity ( 1 to $3 \mathrm{~m}$ depth) measured at the 4 sampling stations was not significantly different $(\mathrm{p}>$ 0.50 ) on 12 of the 22 sampling days. Of those $12 d$, comparisons of mean fluorescence (1 to $3 \mathrm{~m}$ depth) between farm and the reference stations detected significant differences on only $5 \mathrm{~d}(\mathrm{p}<0.05)$. How- ever, significant reductions in chl $a$ on each of these $5 \mathrm{~d}$ was not detected at all of the farm stations.

As noted above, the high-resolution 3D Acrobat survey data showed that water density in the survey domain was sufficiently spatially uniform on 1 September 2010 and 10 May 2011 to permit the accurate calculation of chl $a$ and TPM depletion. The remaining Acrobat surveys indicated a high degree of small-scale spatial variability in water density in the region around the farm. On 1 September 2010, chl a and TPM concentrations interpolated over the survey domain and within the 0.5 to $5 \mathrm{~m}$ depth range were relatively low within the mussel farm compared with much of the outside region (Fig. 7). The exception was a plume of depleted water that extended outward from the farm in a westerly direction (Fig. 7), which is consistent with the observed current direction. The TPM data collected on 10 May 2011 also showed reduced levels within the farm, with lowest concentrations observed at the center of the farm (Fig. 8). The spatial distribution of chl $a$ is not shown in Fig. 8, owing to the presence of a strong depth gradient throughout the region that resulted in a complex 2D contour map that reflected both horizontal and vertical chl a variations.

The percentage food depletion inside the mussel farm was greatest on 1 September 2010 and reached a maximum of approximately $80 \%$ for both chl $a$ and TPM (Fig. 9) compared with a maximum of approximately $50 \%$ depletion of TPM on 10 May 2011 (Fig. 10). The percentage food depletion averaged within the total farmed volume $\left(D_{\mathrm{f}}\right)$ on the 2 different sampling days varied between 13 and $31 \%$, with slightly higher depletion of chl a relative to TPM (Table 3). The chl a depth gradient on 10 May 2011, which prevented presentation of a depth-integrated contour map in Fig. 8, was present in both the farm and reference areas, permitting the calculation of average farm-scale chl a depletion. Food depletion measured at different distances across the farm $\left(D_{x}\right)$ are also presented in Table 3. Depletion across the total farm distance (in the prevailing current direction) averaged $45 \%$ for both TPM and chl a on 1 September 2011, but averaged only approximately $5 \%$ on 10 May 2011. In contrast, depletion to the central part of the farm was $37 \%$ in 2010 and 33\% in 2011 (Table 3).

\section{Depletion model}

Mussel densities employed in the model were $616 \pm 430$ and $309 \pm 180$ ind. $\mathrm{m}^{-3}$ (mean $\pm \mathrm{SD}$ ) in September and May, respectively. Based on the meas- 

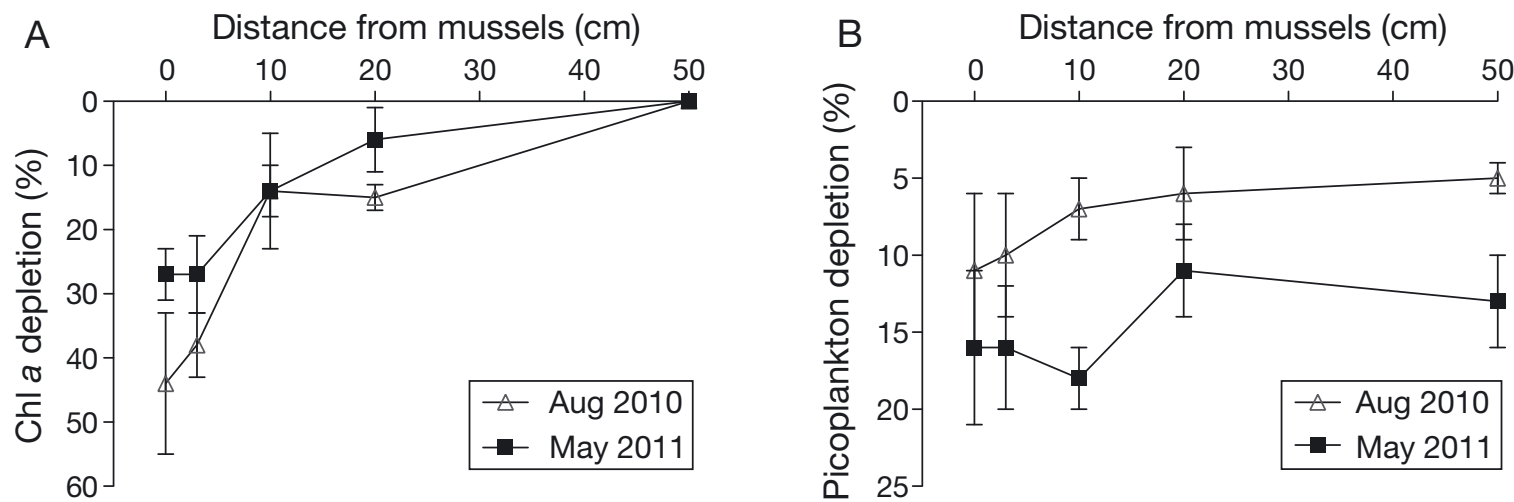

Fig. 6. Mean $( \pm \mathrm{SE})$ depletion percentages of $(\mathrm{A}) \mathrm{chl}$ a $(\mathrm{n}=10$ in August and 12 in May; retained on $0.7 \mu \mathrm{m}$ porosity filters) measured at different distances from the mussel rope sampled in August 2010 and May 2011 by siphon mimics at 2 m depth, and (B) the picoplankton fraction (measured here as between 0.7 to $3 \mu \mathrm{m}$ diameter) at different distances from the mussel rope

ured chl a depletion levels at the centre of the farm (Table 3), the model estimated a realized CR of $0.60 \mathrm{l}$ $\mathrm{h}^{-1}\left(6.94 \times 10^{-9} \mathrm{~m}^{3} \mathrm{~s}^{-1}\right)$ and $1.261 \mathrm{~h}^{-1}\left(14.58 \times 10^{-9} \mathrm{~m}^{3}\right.$ $\mathrm{s}^{-1}$ ) (Eq. 4) and growth rates of $4.1 \mathrm{~d}^{-1}$ and $1.6 \mathrm{~d}^{-1}$ (Eq. 5 ) for September and May, respectively (Table 4). In the model scenarios, increasing mussel density resulted in exponentially lower downstream chl a concentrations (Fig. 11). The target threshold of $1 \mathrm{mg}$ $\mathrm{m}^{-3}$ was reached at 1500 and 1000 ind. $\mathrm{m}^{-3}$ on 1 September and 10 May, respectively (Fig. 11). The population filtration rate increased with higher number of mussels and was similar at around $5 \mathrm{~g} \mathrm{DW} \mathrm{m}^{-3} \mathrm{~d}^{-1}$ for the 2 days (Fig. 12). These results suggest that mussel-stocking levels at the farm are below the capacity of the farmed mussels to capture nutrients and clarify the water column. The density of mussels in the farm could almost be doubled and still maintain a food concentration within the farm of $\geq 1 \mathrm{mg} \mathrm{m}^{-3}$ (Fig. 11).

\section{DISCUSSION}

The mussel growth data indicated that the farm in Skive Fjord was under-utilized in terms of production of mussel biomass, water clarification capacity and nutrient extraction. The specific growth rates of mussels were 48 to $98 \%$ of maximum except during winter. In addition, there was no significant difference in dry tissue growth or mussel biomass on ropes ( $\mathrm{kg} \mathrm{WW} \mathrm{m}^{-1}$ ) between the 3 farm sections (Table 2),

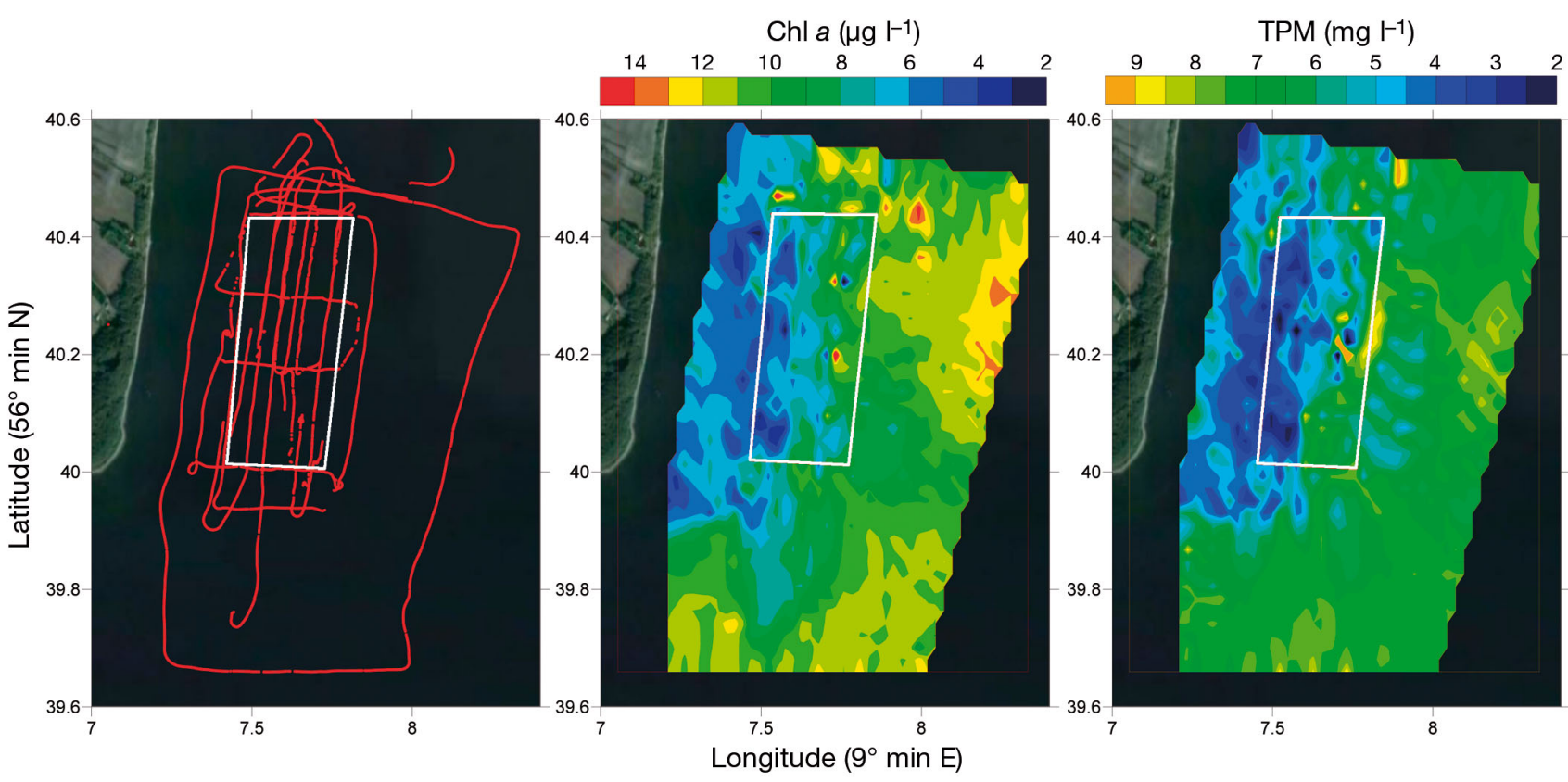

Fig. 7. Acrobat tow track on 1 September 2010 in Limfjorden (left) and contour maps of chl a and total suspended particulate matter (TPM) integrated over the 0.5 to $5 \mathrm{~m}$ depth range. White polygon: location of the mussel farm; red line: survey route 


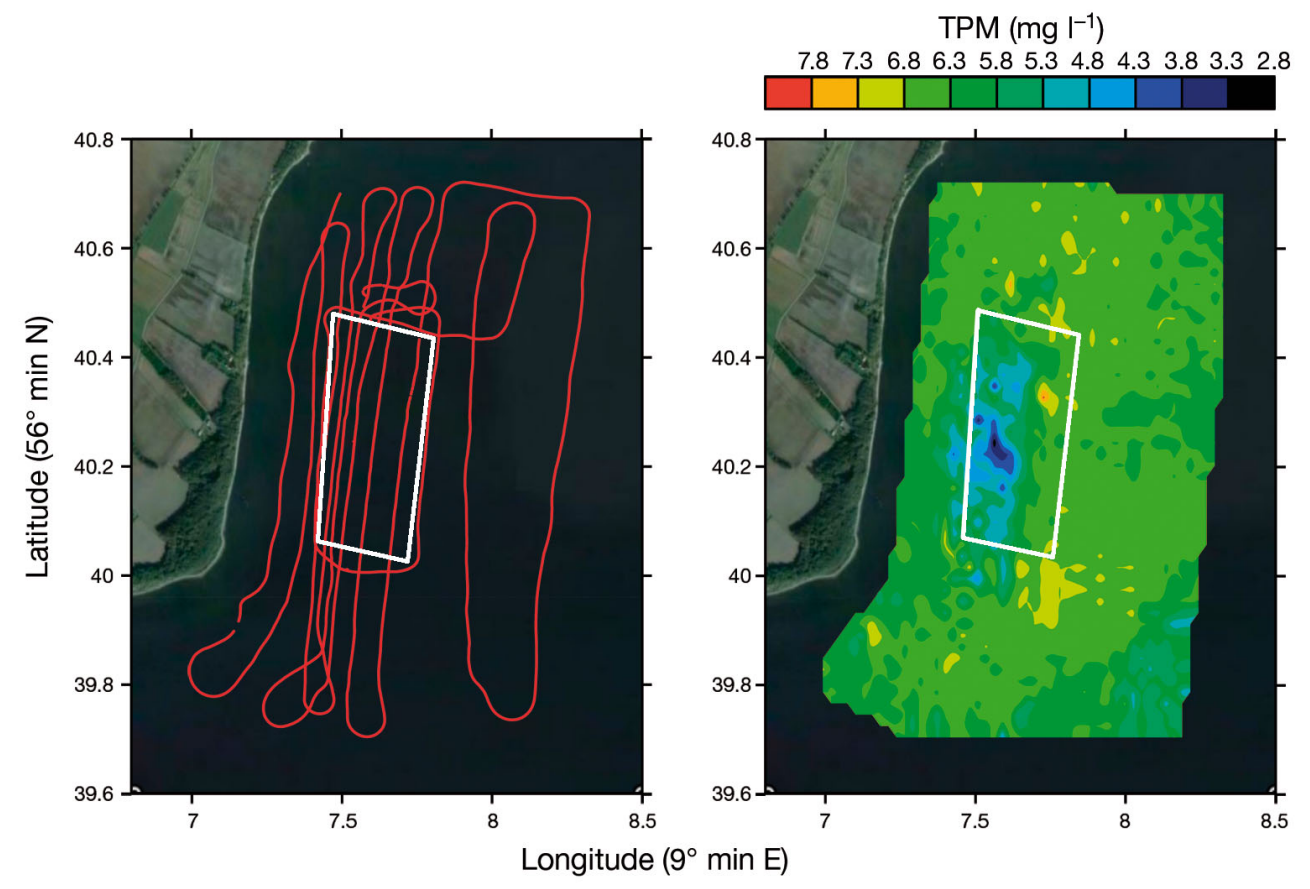

Fig. 8. Acrobat tow track (red) on 10 May 2011 in the Limfjorden (left) and contour map of total suspended particulate matter (TPM) integrated over the 0.5 to $5 \mathrm{~m}$ depth range. Chl a data were not mapped as in Fig. 7 , owing to a strong depth gradient. White polygon: location of the mussel farm

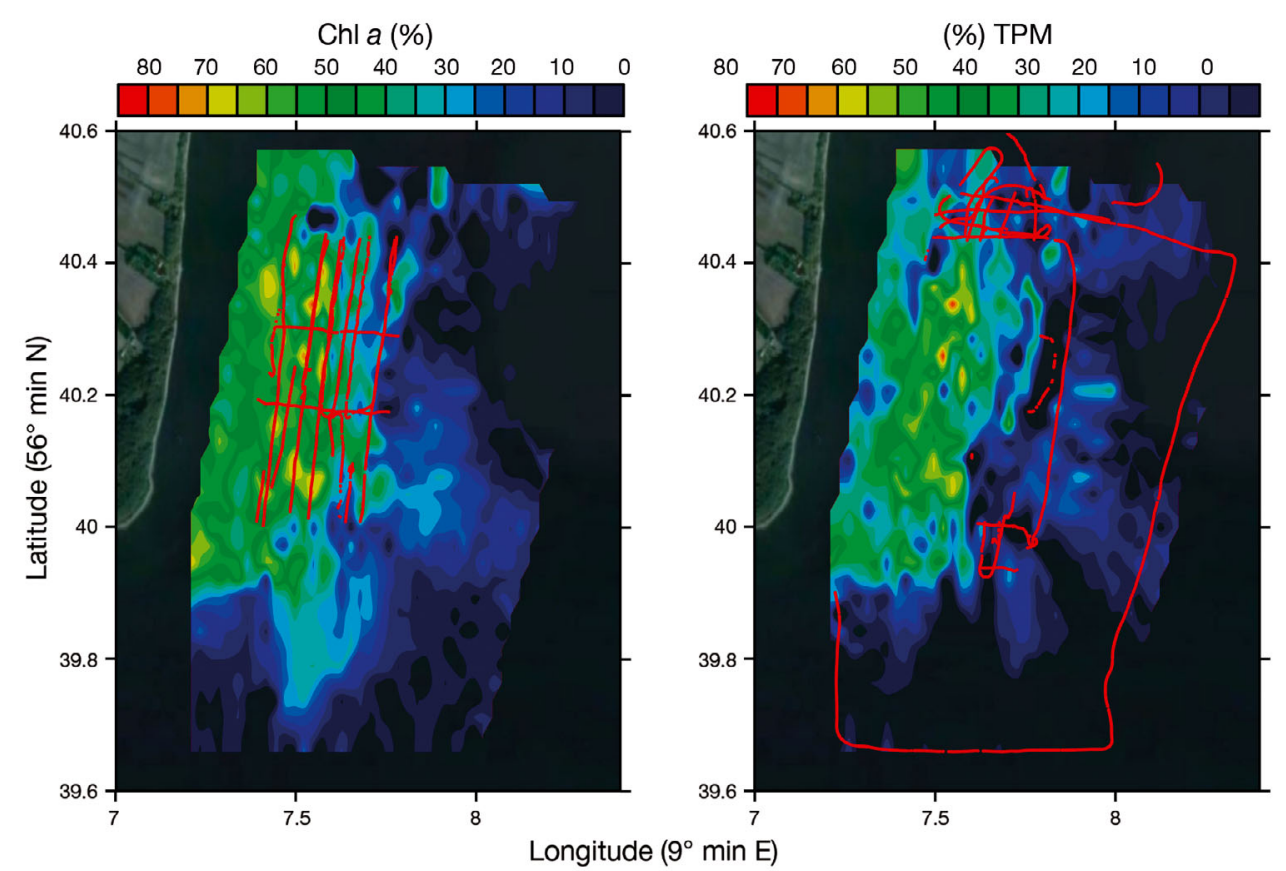

Fig. 9. Contour maps of the percentage depletion of chl a and total particulate matter (TPM) in the vicinity of the Limfjorden experimental mussel farm on 1 September 2010. The locations of data collected inside the mussel farm are indicted as red dots in the left plot and the reference data are similarly shown in the right. Note that the reference area excluded data collected to the west of the farm

or between the center and edge lines of the farm (Fig. 3). These results indicate that mussel growth was not food limited during the 2010-2011 growth season and that the production carrying capacity of the farm had not been not reached even though this nutrient extractive farm was more densely packed than a typical Danish commercial mussel farm. Consequently, the ecosystem services provided by 
the Skive Fjord nutrient extractive farm could be increased.

The water clarification capacity of the mussels was demonstrated at the spatial scale of individual mussel

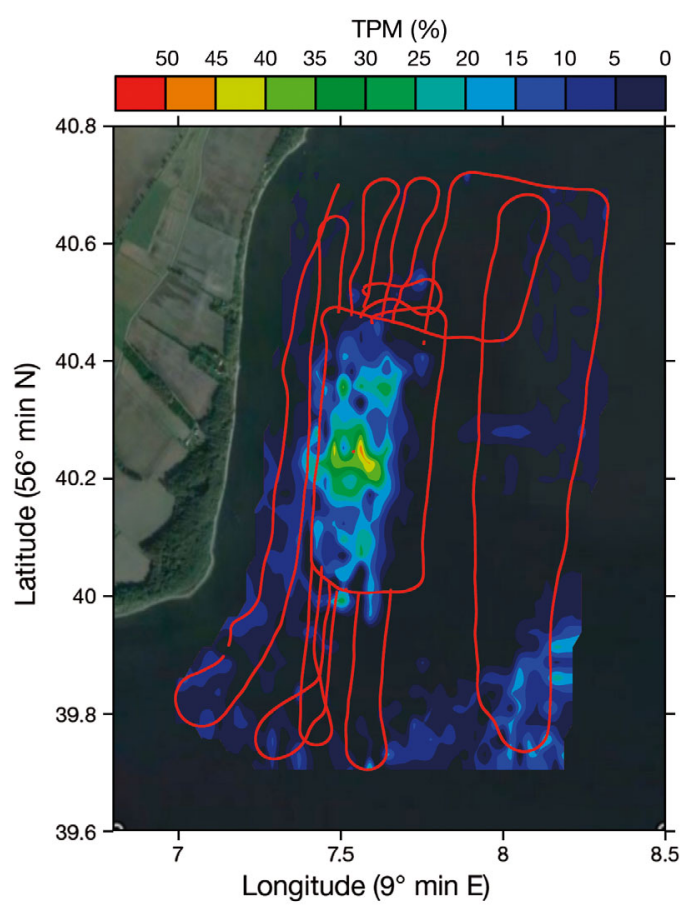

Fig. 10. Contour map of the percentage depletion of total particulate matter (TPM) in the vicinity of the Limfjorden experimental mussel farm on 10 May 2011. The map was generated using all data collected along the Acrobat tow track shown in Fig. 8. TPM depletion inside the farm boundaries, calculated using Eq. (2), is relative to the average TPM concentration collected outside the farm $\left(C_{0}\right.$; red line) ropes as well as the whole farm. The siphon mimic experiments showed small-scale depletion of phytoplankton on 6 of 7 sampling days during both field campaigns, with an effective mussel 'feeding zone' of 10 to $20 \mathrm{~cm}$ (Fig. 6A). This zone is in accordance with previous observations of chl a depletion gradients above mussel beds (e.g. Muschenheim \& Newell 1992, Dolmer 2000a, Nielsen \& Maar 2007, Petersen et al. 2013, Saurel et al. 2013). The average chl a depletion of $27 \%$ (May) and $44 \%$ (August) was lower than the 63 to $74 \%$ reduction reported by Petersen et al. (2008), who used the siphon mimic method at a raft culture of Mytilus galloprovincialis in Spain. The higher depletion at the Spanish site may be explained by the higher rope stocking biomass (15 kg $\mathrm{m}^{-1}$ ) reported in that study compared with the stocking levels shown in Table 1.

Although farm-scale food depletion could not be detected by profile sampling at discrete farm and references stations, the intensive 3D spatial survey approach detected reductions in phytoplankton (chl a) and total seston (TPM) concentrations within the farm $\left(D_{\mathrm{f}}\right)$ of between 13 and $31 \%$ during the 2 sampling periods (Table 3 ). The depletion of both phytoplankton and total seston was similar, with $<5 \%$ difference in $D_{\mathrm{f}}$ estimates (Table 3 ); similar spatial patterns were observed (Fig. 9). The replication of results using chl a and turbidity sensors provides a high level of confidence in the food depletion estimates. Food depletion levels in excess of $50 \%$ occurred in some sections of the farm (Figs. $9 \& 10$ ). The presence of a food depletion maximum in the

Table 3. Percentage seston depletion averaged within the total farm volume $\left(D_{\mathrm{f}}\right)$ and at different distances in the water flow direction across the farm $\left(D_{x}\right) . D_{\mathrm{f}}$ is based on differences in average concentrations of total particulate matter (TPM) or phytoplankton $(\mathrm{chl} a)$ in the farm and reference areas. $D_{x}$ was calculated using Acrobat survey data collected immediately adjacent to the farm boundary on the inflow side (Reference) and on parallel sections on the opposite side (Width) and middle (Centre) of the farm. Numbers in parenthesis are $\pm 2 \mathrm{SE}$, and N. -: not applicable

\begin{tabular}{|c|c|c|c|c|c|}
\hline Parameter & Region & Reference & Farm & $D_{\mathrm{f}}(\%)$ & $D_{x}(\%)$ \\
\hline \multicolumn{6}{|c|}{1 September 2010: $0.5-5 \mathrm{~m}$ depth range; $270^{\circ}$ current direction } \\
\hline \multirow[t]{3}{*}{$\mathrm{TPM}\left(\mathrm{mg} \mathrm{l}^{-1}\right)$ : } & Mean & $6.16(0.04,4207)$ & $4.51(0.04,4765)$ & 26.8 & - \\
\hline & Width & $6.56(0.18,238)$ & $3.65(0.06,767)$ & - & 44.5 \\
\hline & Centre & $6.56(0.18,238)$ & $4.19(0.07,1011)$ & - & 36.3 \\
\hline \multirow[t]{3}{*}{ Chl a $\left(\mu g \mathrm{l}^{-1}\right)$ : } & Mean & $9.89(0.06,4207)$ & $6.78(0.05,4765)$ & 31.4 & - \\
\hline & Width & $10.26(0.19,238)$ & $5.64(0.09,767)$ & - & 45.0 \\
\hline & Centre & $10.26(0.19,238)$ & $6.41(0.09,1011)$ & - & 37.5 \\
\hline \multicolumn{6}{|c|}{10 May 2011: $1-5 \mathrm{~m}$ depth range; $180^{\circ}$ current direction } \\
\hline \multirow[t]{3}{*}{ TPM $\left(\mathrm{mg} \mathrm{l}^{-1}\right)$ : } & Mean & $6.32(0.02,6851)$ & $5.50(0.05,1803)$ & 12.9 & - \\
\hline & Width & $6.33(0.05,667)$ & $6.06(0.13,308)$ & - & 4.3 \\
\hline & Centre & $6.33(0.05,667)$ & $4.55(0.16,190)$ & - & 28.0 \\
\hline \multirow[t]{3}{*}{ Chl a $\left(\mu g \mathrm{l}^{-1}\right)$ : } & Mean & $8.30(0.04,6851)$ & $6.81(0.09,1803)$ & 18.0 & - \\
\hline & Width & $8.79(0.16,667)$ & $8.26(0.18,308)$ & - & 6.1 \\
\hline & Centre & $8.79(0.16,667)$ & $5.91(0.26,190)$ & - & 32.7 \\
\hline
\end{tabular}


Table 4. Environmental and mussel farm variables (mean \pm SD) used in the depletion model for the 2 campaign days and the model estimated clearance rate $(\mathrm{CR})$ and growth rate

\begin{tabular}{|lcc|}
\hline & 1 September 2010 & 10 May 2011 \\
\hline Current direction & East-West & North-South \\
Current speed inside farm $\left(\mathrm{m} \mathrm{s}^{-1}\right)$ & $0.027 \pm 0.013$ & $0.027 \pm 0.008$ \\
Upstream current speed $\left(\mathrm{m} \mathrm{s}^{-1}\right)$ & $0.035 \pm 0.018$ & $0.037 \pm 0.009$ \\
Average current speed $\left(\mathrm{m} \mathrm{s}^{-1}\right)$ & $0.031 \pm 0.023$ & $0.032 \pm 0.005$ \\
Mussel density (ind. $\left.\mathrm{m}^{-3}\right)$ & $616 \pm 430$ & $309 \pm 180$ \\
Distance to the farm centre $(\mathrm{m})$ & 125 & 100 \\
Chl a depletion ratio $\left(C_{X} / C_{0}\right)$ & 0.62 & 0.67 \\
Estimated realized CR $\left(\mathrm{l} \mathrm{h}^{-1}\right)$ & 0.60 & 1.26 \\
Growth rate $\left(\mathrm{d}^{-1}\right)$ & 4.1 & 1.6 \\
\hline
\end{tabular}

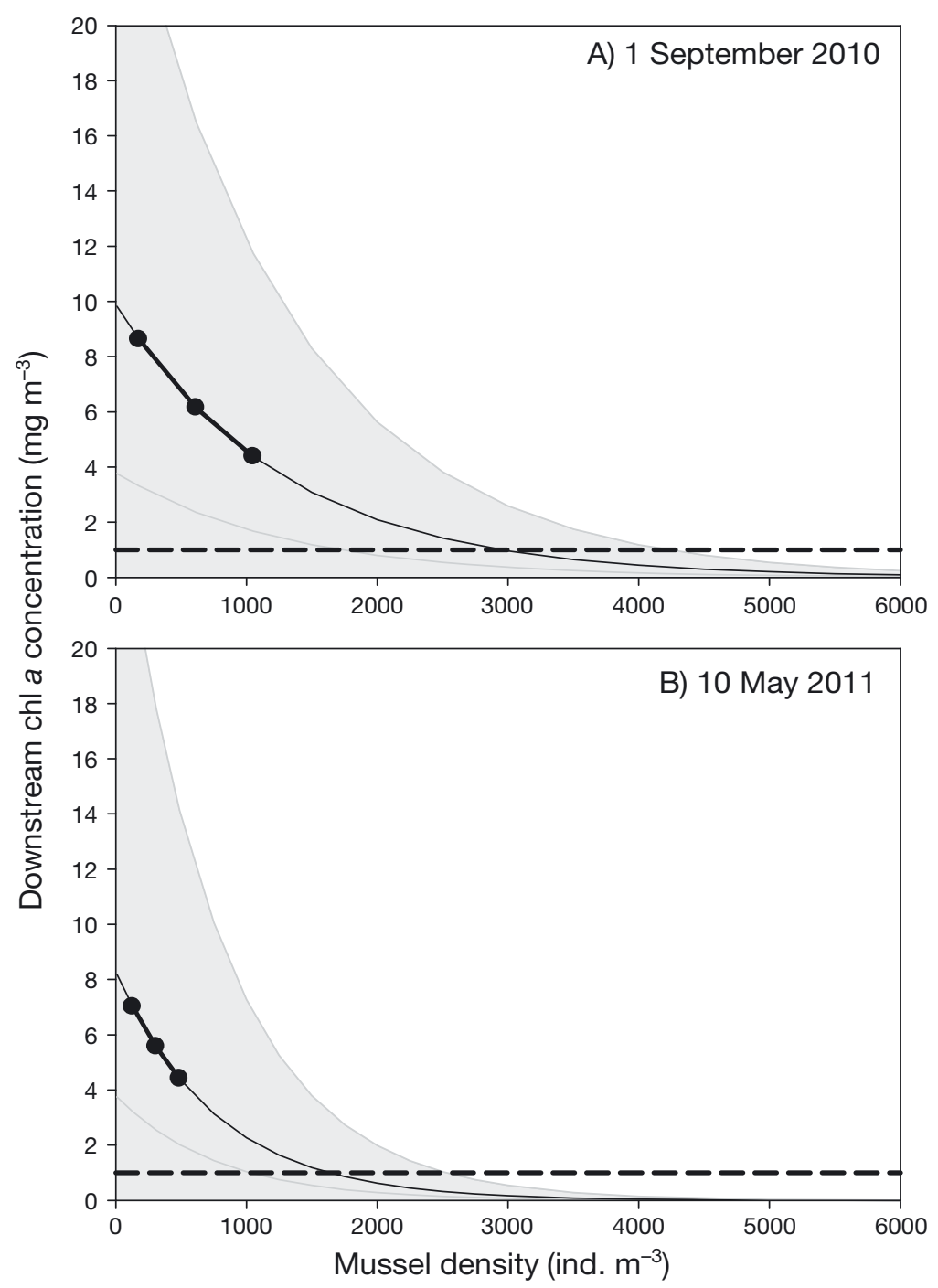

Fig. 11. Model scenario of increasing mussel densities and the effect on downstream chl a concentrations on 2 campaign days. Grey area: effect of changing the upstream average chl a concentrations within the observed annual range at Stn C (Fig. 1). Solid black line: range of observed mussel density (mean $\pm 1 \mathrm{SD}$ ); thick line: actual data; thin line: model (incl. actual data). Grey lines: 95\% confidence interval. Black dashed line: lower threshold (where Danish studies have shown mussels to reduce their clearance rates) center of the mussel farm on 10 May 2011 was also observed by Petersen et al. (2008) at a mussel raft in Spain. This phenomenon may result from entrainment of water into the farm from the raft sides, and enhanced mixing near the outflow side of the farm. Both processes are associated with interactions between the flow around the mussel farm and the reduced flow through the farm caused by drag from mussel structures (Cranford et al. 2014). Measurements of food depletion for the middle of the farm (Table $3 ; D_{x}$ for center region) were higher in September 2010 (36 to 38\% lower than outside the farm) than in May 2011 (28 and 33\%). The higher depletion on the former date occurred despite the presence of smaller mussels with a relatively low feeding rate compared with the larger mussels present in 2011. Mussel densities were reduced by half through self-thinning between these sampling periods (Table 1), and approximately $25 \%$ of the long-lines in the farm had been harvested or removed by ice. The feeding pressure on the food supply during May 2011 was therefore reduced compared with September 2010.

On 1 September 2010, when the current was flowing towards the west, TPM and chl a concentrations declined markedly from the inflow to outflow side of the farm and a plume of depleted water extended to the west of the farm towards the shoreline (Figs. 7 \& 9). However, on 10 May 2011, when the current was flowing to the south, no plume of depleted water was observed to exit the farm (Figs. 8 \& 10). The presence of the shoreline and the rapid decrease in water depth to the west of the farm may exacerbate food depletion by reducing outflow and increasing water retention time inside the farm. The interaction of water flow with coastal morphology, in addition to the above noted changes in mussel biomass between sampling dates, help to explain the higher levels of food depletion occurring in September 2010 compared with the latter observations. When the water flow through the farm was less impeded by bottom drag on 10 May 2011, average 


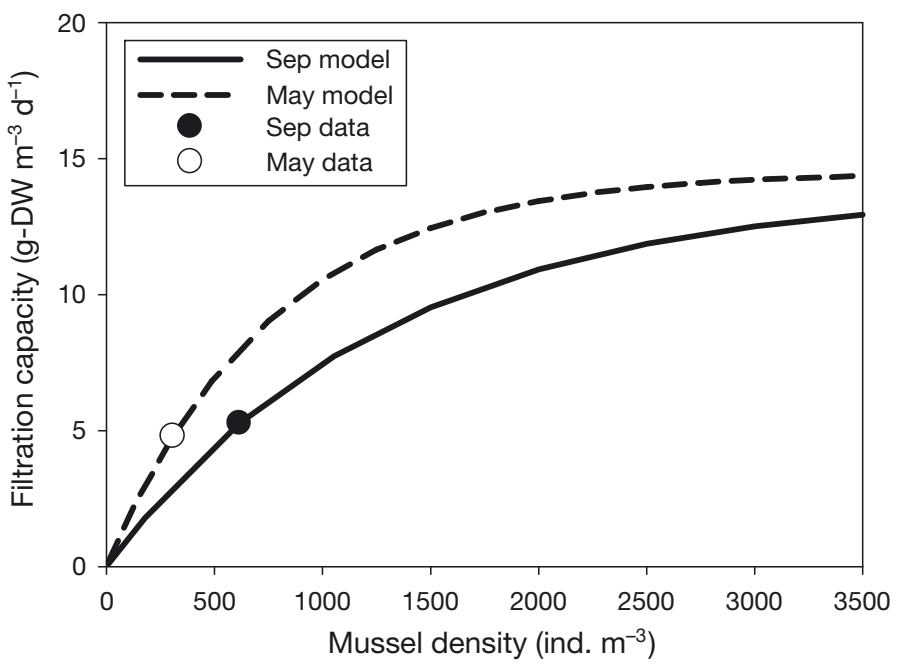

Fig. 12. Filtration capacity as a function of mussel densities (lines) and average mussel density (circles) on 2 campaign days (1 September 2010 and 10 May 2011)

food depletion within and across the farm was lower (Table 3).

Considering that mussel growth, food limitation and seston depletion are interrelated (e.g. Fuentes et al. 2000, Aure et al. 2007, Strohmeier et al. 2008, Rosland et al. 2011) the lack of significant spatial variations in mussel growth within the Skive Fjord farm appear to conflict with the results showing high levels of food depletion in this farm. Several previous studies have reported differences in mussel growth within different sections of a farm (Navarro et al. 1991, Grant et al. 1993, Heasman et al. 1998, Strohmeier et al. 2005, 2008) and have quantified the degree of food depletion (Pérez Camacho et al. 1991, Heasman et al. 1998, Strohmeier et al. 2005, 2008, Cranford et al. 2008, 2014, Petersen et al. 2008). However, these studies were conducted at lower chl a concentrations $\left(<6 \mu \mathrm{g}^{-1}\right)$ than reported herein for the Skive Fjord (Fig. 5, Table 3), and according to Petersen et al. (2008) and Strohmeier et al. (2005), lower individual growth rates related to food depletion will occur more often in areas with low food concentrations than in nutrient-rich areas. Since Skive Fjord is highly eutrophic (Maar et al. 2010, Carstensen et al. 2013, Tomczak et al. 2013), the mussel farm was generally supplied with high food concentrations throughout most of the year (Fig. 5). Despite the steep depletion gradients shown in Fig. 6A, chl a concentrations were still relatively high $(11.9 \pm 5.4$ in May and $7.4 \pm 2.2 \mu \mathrm{g} \mathrm{chl} \mathrm{a} \mathrm{l}^{-1}$ in August) just $0.1 \mathrm{~cm}$ away from the mussel ropes. Chl $a$ and TPM concentrations also did not decrease below $2 \mu \mathrm{g} \mathrm{l}^{-1}$ or $2 \mathrm{mg}$ $1^{-1}$, respectively, at any location within the mussel farm and the zone of maximum food depletion did not consistently occur in the same location (Figs. 7 \& 8). These data indicate that the replenishment of the food supply to the mussels was sufficient to prevent mussel growth being food limited due to food depletion. Furthermore, mussel filtration and other physiological components of growth are related to food concentration (reviewed by Cranford et al. 2011), resulting in a non-linear relationship between food abundance and growth.

The discrete CTD/salinity profiles and the towedvehicle surveys showed a high degree of spatial and temporal variation in the physical and biological properties of the water column in the Skive Fjord during this study. On many of the sampling dates, different density water masses were simultaneously present within the farm. These masses often contained different food concentrations, such that a highly variable food supply was provided to the mussels. Farm-scale food depletion could only be measured for 2 of the 7 Acrobat survey dates as a result of the presence of water mass variability within the farm. This is purely a methodological limitation and it may be expected that the mussels were continuously feeding and depleting the food supply. The high variability in food supply is a possible additional reason why there was no significant difference in mussel growth detected between the edge and middle of the farm (Figs. $2 \& 3$, Table 2). In order for mussel growth to reflect spatial patterns in food depletion, the natural spatial variation in the food supply would have to be less than the variation induced by mussel feeding. Small-scale patchiness in the supply of food to the farm appears to dominate over food depletion as a factor limiting mussel growth in this region.

Model predictions of the impact of increasing mussel stocking on the available food supply (Fig. 11) were conducted in this study to estimate the optimal farm stocking density for increasing water quality and extracting excess phytoplankton in this highly eutrophic setting. Optimization of commercial shellfish culture is based on the production carrying capacity concept, which is the cultured biomass and/ or growth rate that can be sustained by available food in a given area (Grant \& Filgueira 2011). The optimal stocking of a nutrient extraction facility may be expected to be similarly constrained given that the objective is also to harvest the maximum biomass from the farm over a given time, albeit with less concern over product quality. Carrying capacity models generally follow an ecophysiological approach that simulates the physiological components of shellfish growth, including water clearance rates. Mussel CRs 
are related to site-specific population dynamics and environmental change (e.g. Filgueira et al. 2010, Cranford et al. 2011, Petersen et al. 2013, Riisgård et al. 2013) and are therefore best predicted after obtaining extensive measurements. An alternative is to obtain realized CR information based on the backcalculation of the effect of shellfish grazing on the food supply (Aure et al. 2007) or growth (Fréchette \& Bacher 1998). The realized CRs of mussels at the Skive Fjord farm (Table 4), calculated based on Eq. (4) for the $2 \mathrm{~d}$ when farm-scale food depletion was measured, were used to model mussel growth (Eq. 7) and food depletion (Eq. 2) at increasing stocking densities, as a means towards predicting the optimal stocking density.

The estimated realized CRs were 0.60 and 1.261 $\mathrm{h}^{-1}$, respectively, on 1 September 2010 and 10 May 2011. According to Cranford et al. (2011), the 0.14 and $0.55 \mathrm{~g}$ DW mussels (September 2010 and May 2011, respectively) fed natural seston may be expected to exhibit average CRs of 1.0 and $2.3 \mathrm{l} \mathrm{h}^{-1}$, respectively, whereas maximal CRs obtained in laboratory studies with optimal algal-cell diets may be expected to average $1.8 \mathrm{l} \mathrm{h}^{-1}$ for a $0.14 \mathrm{~g}$ mussel and $4.9 \mathrm{l} \mathrm{h}^{-1}$ for a $0.55 \mathrm{~g}$ mussel (Møhlenberg \& Riisgård 1979, Riisgård \& Møhlenberg 1979). Consequently, the estimated realized CR for each date is 40 to $74 \%$ lower than published values. Experimental CR values may be expected to overestimate the realized rate under some conditions, as a result of water refiltration by multiple mussels during passage through a farm, particularly during periods of low flow. Experimental CR measurements are required to be conducted under controlled conditions that prevent water re-filtration by the mussel(s) (e.g. Filgueira et al. 2006). However, the siphon mimic experiments showed that the effective 'feeding zone' of a mussel is of a length-scale that would influence the food supply of neighboring mussels. The food depletion model developed for Spanish mussel raft culture (Cranford et al. 2014) accounted for this re-filtration effect by including a function that simulates the relationship between flow-speed, water re-filtration and CR. They concluded that neglecting the effects of re-filtration on $\mathrm{CR}$ will otherwise result in large overestimates of food depletion during periods of relatively low current speeds $\left(<2 \mathrm{~cm} \mathrm{~s}^{-1}\right)$. Mussel structure drag can have a large effect on water flow through a mussel farm and on food depletion (Cranford et al. 2014 and references therein). The present model (Eq. 4) uses the mean current speed in the middle of the farm to provide an approximation of the net effect of drag-induced flow reduction on current speed and the related effect on CR caused by water re-filtration.

The effect of water re-filtration on mussel CR within a farm will be highly site- and time-specific as a result of the interacting influences of mussel density and size, current speed, the orientation of mussel structures in a farm and circulation patterns around single and multiple mussel structures. To our knowledge, there are only a few other studies that have calculated realized mussel farm CRs (Aure et al. 2007, Petersen et al. 2008). Based on different model assumptions, Aure et al. (2007) estimated a mean realized CR of 1.3 to $2.7 \mathrm{l} \mathrm{h}^{-1}$. Given that no mussel size was reported in that study for comparison with published CR values, it is not possible to determine if these realized rates are also lower than experimental values. Petersen et al. (2008) reported a realized CR value of $2.9 \mathrm{l} \mathrm{h}^{-1}$, which is 60 to $90 \%$ of potential CRs for similar sized mussels. A realized CR value of $0.171 \mathrm{~h}^{-1}$ was reported for bottom mussels in a different area of the Limfjorden (Petersen et al. 2013). Saurel et al. (2013) reported an average realized CR value of $2.93 \pm 1.56 \mathrm{l} \mathrm{h}^{-1}$ in the tidal driven Menai Strait, North Wales, UK, were turbulent mixing prevents re-filtration. In all cases, the realized CR of dense mussel populations was lower than reported for individuals measured under optimal flow and/or dietary conditions.

The optimal stocking density of the farm was defined by setting a target phytoplankton biomass

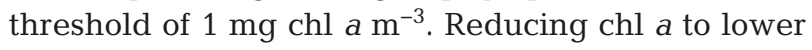
levels may not be possible due to the observed cessation of mussel feeding at lower concentrations in this type of environment (Dolmer 2000b, Riisgård et al. 2006, Saurel et al. 2007). Based on this threshold, the results of the depletion model (based on Eqs. 2 \& 6) indicate that the mussel population filtration rate could be increased by 80 to $120 \%$ in order to reach the target threshold. This could be accomplished by approximately doubling the standing stock of mussels in the farm (Fig. 12) and still maintaining a food concentration within the farm of $\geq 1 \mathrm{mg} \mathrm{m}^{-3}$ (Fig. 11). This would represent a dramatic increase in water clarity over current conditions (Fig. 5). An option for reaching the desired increase in stocking may be to decrease the intervals between loop attachment points on the existing long-lines. A doubling of the standing stock of mussels would result in a net removal of $32 \mathrm{t} \mathrm{N}$ and $1.4 \mathrm{t} \mathrm{P}$ using the measured $\mathrm{N}$ and P-contents for May 2011 (Table 1) reported by Petersen et al. (2014). This corresponds to $\mathrm{N}$ removal of $1.8 \mathrm{t} \mathrm{ha}^{-1} \mathrm{yr}^{-1}$. This estimate is higher than the removal of 0.1 to $0.7 \mathrm{tha}^{-1} \mathrm{yr}^{-1}$ estimated by the 
FARM-model for long-line cultures of Mytilus spp. at 3 other European sites (Rose et al. 2015) and is also higher than the removal of $1.1 \mathrm{t} \mathrm{ha}^{-1} \mathrm{yr}^{-1}$ estimated in a field study on the Swedish west coast (Lindahl et al. 2005).

Achieving the theoretical maximum ecosystem services from extractive culture may be constrained by a number of factors. Mussel density on the ropes decreased by $50 \%$ between September 2010 and May 2011 (Table 1) due to self-thinning. Increasing the density on the rope therefore does not appear to be an option for doubling the mussel stock. The addition of additional long-lines in the farmed area would interfere with service vessel access to the lines. Increasing the mussel biomass within the mussel farm would, on the other hand, cause additional flow reduction (e.g. Petersen et al. 2008, Stevens \& Petersen 2011, Cranford et al. 2014), which would increase water re-filtration by the mussels and reduce realized CRs, growth rates and nutrient extraction. Increasing mussel density may therefore be expected to reach a self-limited threshold for the extraction of excess phytoplankton that is specific to a given area. An additional constraint for optimizing an extractive mussel farm is the possible effects on benthic habitat and communities from the deposition of organic matter in mussel faeces and pseudofaeces. Observations of benthic effects from bivalve farming are generally limited to the immediate vicinity of the farm in shallow, poorly flushed regions (Chamberlain et al. 2001, Hartstein \& Stevens 2005, Hargrave et al. 2008, Carlsson et al. 2009, 2010, Cranford et al. 2009). Benthic impacts at the Skive Fjord mussel farm were shown to be limited compared to the surrounding area due to the high rate of sediment organic enrichment from eutrophication (Holmer et al. 2015). While mussel farming may not improve existing eutrophic benthic conditions under some farms, the removal of excess phytoplankton and nutrients from the water column should result in a net reduction in benthic organic enrichment and associated impacts at the coastal ecosystem scale.

Mussel mitigation farming has focused on the ecological benefits of sequestering excess nutrients that are removed from the system (e.g. Petersen et al. 2015 and references within). However, ancillary ecosystem services from mussel farming include the mediation of additional nutrients in biodeposits being buried in sediments or lost through microbial denitrification (Newell et al. 2004) and the removal of excess phytoplankton and other suspended particulates (e.g. Petersen et al. 2008, 2015, Cranford et al. 2014, Newell \& Richardson 2014), which will en- hance light penetration and water quality (Schröder et al. 2014, Petersen et al. 2015) and reduce the occurrence of anoxic events (Newell 2004). Mussel ropes and anchors can also provide a temporary habitat for other species (Murray et al. 2007, D'Amours et al. 2008, Wilding \& Nickell 2013). Beside these ecological services, the mitigation mussels provide goods for human consumption (Lindahl 2011, Petersen et al. 2014), feed for husbandry (Jönsson \& Elwinger 2009, Jönsson et al. 2011, Nørgaard et al. 2015) and fertilizer (Olrog \& Christensson 2008). Nutrient extraction mussel farms represent an effective bioengineering approach for the provision of positive coastal ecosystem services and economic benefits. However, the availability of this mitigation approach does not negate the need to reduce excess nutrient emissions at the source.

Acknowledgements. We thank Dr. Dave Plew for providing current speed data and for assistance with the towed vehicle surveys. This study is part of the research project 'Production of Mussels-Mitigation and Feed for Husbandry (MuMiHus)' funded by the Danish Council for Strategic Research under grant agreement no. 09-066983. P.N. was funded by The Danish Council for Strategic Research under grant agreement no. 10-078561.

\section{LITERATURE CITED}

Aure J, Strohmeier T, Strand Ø (2007) Modelling current speed and carrying capacity in long-line blue mussel (Mytilus edulis) farms. Aquacult Res 38:304-312

Bacher C, Grant J, Hawkins A, Fang J, Zhu M, Besnard M (2003) Modelling the effect of food depletion on scallop growth in Sungo Bay (China). Aquat Living Resour 16: $10-24$

Carlsson MS, Holmer M, Petersen JK (2009) Seasonal and spatial variations of benthic impacts of mussel longline farming in a eutrophic Danish Fjord, Limfjorden. J Sea Res 28:791-801

Carlsson MS, Glud RN, Petersen JK (2010) Degradation of mussel (Mytilus edulis) fecal pellets released from hanging long-lines upon sinking and after settling at the sediment. Can J Fish Aquat Sci 67:1376-1387

> Carstensen J, Krause-Jensen D, Markager S, Timmermann K, Windolf J (2013) Water clarity and eelgrass responses to nitrogen reductions in the eutrophic Skive Fjord, Denmark. Hydrobiologia 704:293-309

Chamberlain J, Fernandes TF, Read P, Nickell TD, Davies IM (2001) Impacts of biodeposits from suspended mussel (Mytilus edulis L.) culture on the surrounding surficial sediments. ICES J Mar Sci 58:411-416

> Clausen I, Riisgård HU (1996) Growth, filtration and respiration in the mussel Mytilus edulis: no evidence for physiological regulation of the filter-pump to nutritional needs. Mar Ecol Prog Ser 141:37-45

Cloern JE (1982) Does the benthos control phytoplankton in south San Francisco Bay? Mar Ecol Prog Ser 9:191-202 
Cranford PJ, William L, Strand Ø, Strohmeier T (2008) Phytoplankton depletion by mussel aquaculture: high resolution mapping, ecosystem modeling and potential indicators of ecological carrying capacity. ICES CM 2008/H:12. International Council for the Exploration of the Sea, Copenhagen

Cranford PJ, Hargrave BT, Doucette LI (2009) Benthic organic enrichment from suspended mussel (Mytilus edulis) culture in Prince Edward Island, Canada. Aquaculture 292:189-196

Cranford PJ, Ward JE, Shumway SE (2011) Bivalve filter feeding: variability and limits of the aquaculture biofilter. In: Shumway SE (ed) Shellfish aquaculture and the environment. Wiley-Blackwell, Oxford, p 81-124

Cranford PJ, Duarte P, Robinson SMC, Fernández-Reiriz FJ, Labarta U (2014) Suspended particulate matter depletion and flow modification inside mussel (Mytilus galloprovincialis) culture rafts in the Ría de Betanzos, Spain. J Exp Mar Biol Ecol 452:70-81

D'Amours O, Archambault P, McKindsey CW, Johnson LE (2008) Local enhancement of epibenthic macrofauna by aquaculture activities. Mar Ecol Prog Ser 371:73-84

Dame RF (1993) Bivalve filter feeders in estuarine and coastal ecosystem processes. Springer, New York, NY

Dame RF (1996) Ecology of marine bivalves: an ecosystem approach. CRC Press, Boca Raton, FL

> Dolmer P (2000a) Algal concentration profiles above mussel beds. J Sea Res 43:113-119

> Dolmer P (2000b) Feeding activity of mussels Mytilus edulis related to near-bed currents and phytoplankton biomass. J Sea Res 44:221-231

Edebo L, Haamer J, Lindahl O, Loo LO, Piriz L (2000) Recycling of macronutrients from sea to land using mussel cultivation. Int J Environ Pollut 13:190-207

Ferreira JG, Saurel C, Lencarte Silva JD, Nunes JP, Vazquez $\mathrm{F}$ (2014) Modelling of interactions between inshore and offshore aquaculture. Aquaculture 426-427:154-164

> Filgueira R, Labarta U, Fernandez-Reiriz MJ (2006) Flowthrough chamber method for clearance rate measurements in bivalves: design and validation of individual chambers and mesocosm. Limnol Oceanogr Methods 4: 284-292

> Filgueira R, Fernandez-Reiriz MJ, Labarta U (2010) Clearance rate of the mussel Mytilus galloprovincialis. II. Response to uncorrelated seston variables (quantity, quality, and chlorophyll content). Cienc Mar 36:15-28

Fréchette M, Bacher C (1998) A modelling study of optimal stocking density of mussel populations kept in experimental tanks. J Exp Mar Biol Ecol 219:241-255

Fuentes J, Gregorio V, Giraldez R, Molares J (2000) Withinraft variability of the growth rate of mussels, Mytilus galloprovincialis, cultivated in the Ría de Arousa (NW Spain). Aquaculture 189:39-52

Grant J, Filgueira R (2011) The application of dynamic modeling to prediction of production carrying capacity in shellfish farming. In: Shumway SE (ed) Shellfish aquaculture and the environment. Wiley-Blackwell, Oxford, $p$ 135-151

Grant J, Dowd M, Thompson K, Emerson C, Hatcher A (1993) Perspectives on field studies and related biological models of bivalve growth. In: Dame R (ed) Bivalve filter feeders and marine ecosystem processes. Springer, New York, NY, p 371-420

Grant J, Bacher C, Cranford PJ, Guyondet T, Carreau M
(2008) A spatially explicit ecosystem model of seston depletion in dense mussel culture. J Mar Syst 73:155-168

> Gren IM, Lindahl O, Lindqvist M (2009) Values of mussel farming for combating eutrophication: an application to the Baltic Sea. Ecol Eng 35:935-945

Haamer J (1996) Improving water quality in a eutrophied fjord system with mussel farming. Ambio 25:356-362

> Hamburger K, Møhlenberg F, Randlov A, Riisgård HU (1983) Size, oxygen consumption and growth in the mussel Mytilus edulis. Mar Biol 75:303-306

Hargrave BT, Doucette LI, Cranford PJ, Law BA, Milligan TG (2008) Influence of mussel aquaculture on sediment organic enrichment in a nutrient-rich coastal embayment. Mar Ecol Prog Ser 365:137-149

Hart R (2003) Dynamic pollution control-time lags and optimal restoration of marine ecosystems. Ecol Econ 47: 79-93

> Hartstein ND, Stevens SL (2005) Deposition beneath longline mussel farms. Aquacult Eng 33:192-213

Heasman K, Pitcher G, McQuaid C, Hecht T (1998) Shellfish mariculture in the Benguela system: raft culture of Mytilus galloprovincialis and the effect of rope spacing on food extraction, growth rate, production, and condition of mussels. J Shellfish Res 17:33-39

Holm-Hansen O, Lorenzen C, Holmes R, Strickland J (1965) Fluorometric determination of chlorophyll. ICES J Mar Sci 30:3-15

Holmer M, Thorsen SW, Carlsson MS, Petersen JK (2015) Pelagic and benthic nutrient regeneration processes in mussel cultures (Mytilus edulis) in a eutrophic coastal area (Skive Fjord, Denmark). Estuaries Coasts 38:1629-1641

Jönsson L, Elwinger K (2009) Mussel meal as a replacement for fish meal in feeds for organic poultry-a pilot shortterm study. Acta Agric Scand A Anim Sci 59:22-27

> Jönsson L, Wall H, Tauson R (2011) Production and egg quality in layers fed organic diets with mussel meal. Animal 5:387-393

> Landes A, Dolmer P, Poulsen LK, Petersen JK, Vismann B (2015) Growth and respiration in blue mussels (Mytilus spp.) from different salinity regimes. J Shellfish Res 34: 373-382

Lindahl O (2011) Mussel farming as a tool for re-eutrophication of coastal waters: experiences from Sweden. In: Shumway S (ed) Shellfish aquaculture and the environment. Wiley-Blackwell, Oxford, p 217-237

> Lindahl O, Kollberg S (2009) Can the EU agri-environmental aid program be extended into the coastal zone to combat eutrophication? Hydrobiologia 629:59-64

> Lindahl O, Hart R, Hernroth B, Kollberg S and others (2005) Improving marine water quality by mussel farming: a profitable solution for Swedish society. Ambio 34:131-138

> Maar M, Nielsen TG, Petersen JK (2008) Depletion of plankton in a raft culture of Mytilus galloprovincialis in Ría de Vigo, NW Spain. II. Zooplankton Aquat Biol 4: $127-141$

> Maar M, Timmermann K, Petersen JK, Gustafsson KE, Storm LM (2010) A model study of the regulation of blue mussels by nutrient loadings and water column stability in a shallow estuary, the Limfjorden. J Sea Res 64: 322-333

Møhlenberg F (1999) Effect of meteorology and nutrient load on oxygen depletion in a Danish micro-tidal estuary. Aquat Ecol 33:55-64

Møhlenberg F, Riisgård HU (1979) Filtration-rate, using a 
new indirect technique, in 13 species of suspensionfeeding bivalves. Mar Biol 54:143-147

Murray LG, Newell CR, Seed R (2007) Changes in the biodiversity of mussel assemblages induced by two methods of cultivation. J Shellfish Res 26:153-162

Muschenheim DK, Newell CR (1992) Utilization of seston flux over a mussel bed. Mar Ecol Prog Ser 85:131-136

> Navarro E, Iglesias J, Perez-Camacho A, Labarta U, Beiras R (1991) The physiological energetics of mussels (Mytilus galloprovincialis Lmk) from different cultivation rafts in the Ria de Arosa (Galicia, NW Spain). Aquaculture 94: 197-212

Newell RIE (2004) Ecosystem influences of natural and cultivated populations of suspension-feeding bivalve molluscs: a review. J Shellfish Res 23:51-61

> Newell CR, Richardson J (2014) The effects of ambient and aquaculture structure hydrodynamics on the food supply and demand of mussel rafts. J Shellfish Res 33:257-272

> Nielsen TG, Maar M (2007) Effects of a blue mussel Mytilus edulis bed on vertical distribution and composition of the pelagic food web. Mar Ecol Prog Ser 339:185-198

> Nørgaard JV, Petersen JK, Tørring DB, Jørgensen H, Lærke HN (2015) Chemical composition and standardized ileal digestibility of protein and amino acids from blue mussel, starfish, and fish silage in pigs. Anim Feed Sci Technol 205:90-97

> Nunes JP, Ferreira JG, Bricker SB, O'Loan B and others (2011) Towards an ecosystem approach to aquaculture: assessment of sustainable shellfish cultivation at different scales of space, time and complexity. Aquaculture 315:369-383

Officer CB, Smayda TJ, Mann R (1982) Benthic filter feeding: a natural eutrophication control. Mar Ecol Prog Ser 9:203-210

> Ogilvie SC, Ross AH, Schiel DR (2000) Phytoplankton biomass associated with mussel farms in Beatrix Bay, New Zealand. Aquaculture 181:71-80

> Olesen M, Lundsgaard C (1995) Seasonal sedimentation of autochthonous material from the euphotic zone of a coastal system. Estuar Coast Shelf Sci 41:475-490

Olrog L, Christensson E (2008) Användning av musslor och musselrester som gödselmedel i jordbruket (Use of mussels and mussel waste as fertilizer in agriculture). Hushållningssällskapet Väst Rapport no. 1, Swedish Rural Economy and Agricultural Societies (in Swedish)

> Pascoe PL, Parry HE, Hawkins AJS (2009) Observations on the measurement and interpretation of clearance rate variations in suspension-feeding bivalve shellfish. Aquat Biol 6:181-190

Pérez Camacho A, Gonzalez R, Fuentes J (1991) Mussel culture in Galicia (NW Spain). Aquaculture 94:263-278

Petersen JK (2004) Grazing on pelagic primary producers: the role of benthic suspension feeders in estuaries. In: Nielsen SL, Banta G, Pedersen MF (eds) Estuarine nutrient cycling: the influence of primary producers. Kluwer Academic, Dordrecht, p 129-152

> Petersen JK, Nielsen TG, van Duren L, Maar M (2008) Depletion of plankton in a raft culture of Mytilus galloprovincialis in Ría de Vigo, NW Spain. I. Phytoplankton. Aquat Biol 4:113-125

> Petersen JK, Timmermann K, Carlsson M, Holmer M, Maar M, Lindahl O (2012) Mussel farming can be used as a mitigation tool-a reply. Mar Pollut Bull 64:452-454

Petersen JK, Maar M, Ysebaert T, Herman PMJ (2013) Near- bed gradients in particles and nutrients above a mussel bed in the Limfjorden: influence of physical mixing and mussel filtration. Mar Ecol Prog Ser 490:137-146

Petersen JK, Hasler B, Timmermann K, Nielsen P, Tørring DB, Larsen MM, Holmer M (2014) Mussels as a tool for mitigation of nutrients in the marine environment. Mar Pollut Bull 82:137-143

> Petersen JK, Saurel C, Nielsen P, Timmermann K (2015) The use of shellfish for eutrophication control. Aquacult Int, doi:10.1007/s10499-015-9953-0

> Riisgård HU, Møhlenberg F (1979) Improved automatic recording apparatus for determining the filtration rate of Mytilus edulis as a function of size and algal concentration. Mar Biol 52:61-67

> Riisgård HU, Poulsen E (1981) Growth of Mytilus edulis in net bags transferred to different localities in a eutrophicated Danish fjord. Mar Pollut Bull 12:272-276

> Riisgård HU, Lassen J, Kittner C (2006) Valve-gape response times in mussels (Mytilus edulis) - effects of laboratory preceding-feeding conditions and in situ tidally induced variation in phytoplankton biomass. J Shellfish Res 25: 901-911

Riisgård HU, Lundgreen K, Larsen PS (2012) Field data and growth model for mussels Mytilus edulis in Danish waters. Mar Biol Res 8:683-700

> Riisgård HU, Pleissner D, Larsen PS, Lundgreen K (2013) Growth of mussels Mytilus edulis at algal (Rhodomonas salina) concentrations below and above saturation levels for reduced filtration rate. Mar Biol Res 9:1005-1017

Riisgård HU, Lundgreen K, Larsen PS (2014) Potential for production of 'mini-mussels' in Great Belt (Denmark) evaluated on basis of actual and modeled growth of young mussels Mytilus edulis. Aquacult Int. 22:859-885

Rose JM, Ferreira JG, Stephenson K, Bricker SB, Tedesco M, Wikfors GH (2012) Comment on Stadmark and Conley (2011) Mussel farming as a nutrient reduction measure in the Baltic Sea: consideration of nutrient biogeochemical cycles. Mar Pollut Bull 64:449-451

Rose JM, Bricker SB, Ferreira JG (2015) Comparative analysis of modeled nitrogen removal by shellfish farms. Mar Pollut Bull 91:185-190

Rosland R, Bacher C, Strand Ø, Aure J, Strohmeier T (2011) Modelling growth variability in longline mussel farms as a function of stocking density and farm design. J Sea Res 66:318-330

Saurel C, Gascoigne JC, Palmer MR, Kaiser MJ (2007) In situ mussel feeding behavior in relation to multiple environmental factors: regulation through food concentration and tidal conditions. Limnol Oceanogr 52:1919-1929

Saurel C, Petersen JK, Wiles PJ, Kaiser MJ (2013) Turbulent mixing limits mussel feeding: direct estimates of feeding rate and vertical diffusivity. Mar Ecol Prog Ser 485: 105-121

> Saurel C, Ferreira JG, Cheney D, Suhrbier A, Dewey B, Davis J, Cordell J (2014) Ecosystem goods and services from Manila clam culture in Puget Sound: a modelling analysis. Aquacult Environ Interact 5:255-270

Schröder T, Stank J, Schernewski G, Krost P (2014) The impact of a mussel farm on water transparency in the Kiel Fjord. Ocean Coast Manage 101:42-52

Smaal AC, Vonck A, Bakker M (1997) Seasonal variation in physiological energetics of Mytilus edulis and Cerastoderma edulis of different size classes. J Mar Biol Assoc UK 77:817-838 
Stevens CL, Petersen JK (2011) Turbulent, stratified flow through a suspended shellfish canopy: implications for mussel farm design. Aquacult Environ Interact 2:87-104

Strohmeier T, Aure J, Duinker A, Castberg T, Svardal A, Strand $\varnothing$ (2005) Flow reduction, seston depletion, meat content and distribution of diarrhetic shellfish toxins in a long-line blue mussel (Mytilus edulis) farm. J Shellfish Res 24:15-23

Strohmeier T, Duinker A, Strand Ø, Aure J (2008) Temporal and spatial variation in food availability and meat ratio in a longline mussel farm (Mytilus edulis). Aquaculture
276:83-90

Tomczak MT, Dinesen GE, Hoffmann E, Maar M, Støttrup JG (2013) Integrated trend assessment of ecosystem changes in the Limfjord: Evidence of a recent regime shift? Estuar Coast Shelf Sci 117:178-187

van der Veer HW, Cardoso JFMF, van der Meer J (2006) The estimation of DEB parameters for various Northeast Atlantic bivalve species. J Sea Res 56:107-124

Wilding TA, Nickell TD (2013) Changes in benthos associated with mussel (Mytilus edulis L.) farms on the westcoast of Scotland. PLoS One 8:e68313

Submitted: October 29, 2015; Accepted: February 28, 2016 Proofs received from author(s): April 26, 2016
Editorial responsibility: Catriona MacLeod,

Hobart, Tasmania, Australia 